\title{
Global mapping of randomised trials related articles published in high-impact-factor medical journals: a cross-sectional analysis
}

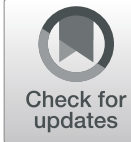

\author{
Ferrán Catalá-López ${ }^{1,2,3^{*}}$ (D), Rafael Aleixandre-Benavent ${ }^{4,5}$, Lisa Caulley ${ }^{3,6,7}$, Brian Hutton ${ }^{3,8}$, \\ Rafael Tabarés-Seisdedos ${ }^{2}$, David Moher ${ }^{3,8}$ and Adolfo Alonso-Arroyo ${ }^{5,9}$
}

\begin{abstract}
Background: Randomised controlled trials (RCTs) provide the most reliable information to inform clinical practice and patient care. We aimed to map global clinical research publication activity through RCT-related articles in highimpact-factor medical journals over the past five decades.

Methods: We conducted a cross-sectional analysis of articles published in the highest ranked medical journals with an impact factor $>10$ (according to Journal Citation Reports published in 2017). We searched PubMed/MEDLINE (from inception to December 31, 2017) for all RCT-related articles (e.g. primary RCTs, secondary analyses and methodology papers) published in high-impact-factor medical journals. For each included article, raw metadata were abstracted from the Web of Science. A process of standardization was conducted to unify the different terms and grammatical variants and to remove typographical, transcription and/or indexing errors. Descriptive analyses were conducted (including the number of articles, citations, most prolific authors, countries, journals, funding sources and keywords). Network analyses of collaborations between countries and co-words are presented.

Results: We included 39,305 articles (for the period 1965-2017) published in forty journals. The Lancet ( $n=3593$; 9.1\%), the Journal of Clinical Oncology $(n=3343 ; 8.5 \%)$ and The New England Journal of Medicine $(n=3275$ articles; 8.3\%) published the largest number of RCTs. A total of 154 countries were involved in the production of articles. The global productivity ranking was led by the United States ( $n=18,393$ articles), followed by the United Kingdom ( $n=8028$ articles), Canada ( $n=4548$ articles) and Germany ( $n=4415$ articles). Seventeen authors who had published 100 or more articles were identified; the most prolific authors were affiliated with Duke University (United States), Harvard University (United States) and McMaster University (Canada). The main funding institutions were the National Institutes of Health (United States), Hoffmann-La Roche (Switzerland), Pfizer (United States), Merck Sharp \& Dohme (United States) and Novartis (Switzerland). The 100 most cited RCTs were published in nine journals, led by The New England Journal of Medicine ( $n=78$ articles), The Lancet ( $n=9$ articles) and JAMA ( $n=7$ articles). These landmark contributions focused on novel methodological approaches (e.g. the "Bland-Altman method") and trials on the management of chronic conditions (e.g. diabetes control, hormone replacement therapy in postmenopausal women, multiple therapies for diverse cancers, cardiovascular therapies such as lipid-lowering statins, antihypertensive medications, and antiplatelet and antithrombotic therapy).
\end{abstract}

(Continued on next page)

\footnotetext{
* Correspondence: ferran_catala@outlook.com

${ }^{1}$ Department of Health Planning and Economics, National School of Public

Health, Institute of Health Carlos III, Madrid, Spain

${ }^{2}$ Department of Medicine, University of Valencia/INCLIVA Health Research

Institute and CIBERSAM, Valencia, Spain

Full list of author information is available at the end of the article
}

(c) The Author(s). 2020 Open Access This article is distributed under the terms of the Creative Commons Attribution 4.0 International License (http://creativecommons.org/licenses/by/4.0/), which permits unrestricted use, distribution, and reproduction in any medium, provided you give appropriate credit to the original author(s) and the source, provide a link to the Creative Commons license, and indicate if changes were made. The Creative Commons Public Domain Dedication waiver (http://creativecommons.org/publicdomain/zero/1.0/) applies to the data made available in this article, unless otherwise stated. 
(Continued from previous page)

Conclusions: Our analysis identified authors, countries, funding institutions, landmark contributions and highimpact-factor medical journals publishing RCTs. Over the last 50 years, publication production in leading medical journals has increased, with Western countries leading in research but with low- and middle-income countries showing very limited representation.

Keywords: Evidence-based medicine, Randomized controlled trial, Scientific collaboration

\section{Background}

Randomised controlled trials (RCTs) are considered one of the simplest and most powerful tools for assessing the safety and effectiveness of treatment interventions [1-3]. When appropriately designed, conducted and reported, RCTs can produce an immediate impact on clinical practice and patient care [4].

The evolution of RCTs has been an enduring and continuing process [5-15]. Since the 1970s the publication landscape for RCTs has exhibited an exponential growth. For example, a 1965-2001 bibliometric analysis of the literature identified 369 articles published in 1970 compared to 11,159 published in 2000 [5]. The development of clinical trial registries (such as clinicaltrials.gov) $[9,10]$, the exponential increase in journals publishing trial protocols, results and secondary studies, and growing support for data-sharing policies $[11,12]$ have created an open research environment of transparency and accountability. Furthermore, the publication of reporting guidelines (such as CONSORT and SPIRIT) [4, 13-15] have served to facilitate the transition between research and reporting to ensure standardisation and ease of readability.

RCTs published in major medical journals are highly cited and have an instrumental role in clinical practice and health policy decisions $[5,16,17]$. Previous studies have focused on the quality of the reporting of methods and results of RCTs [18-22] and publication practices [23-28] in selected samples of articles published in high-impact-factor (IF) medical journals. However, to the best of our knowledge, no mapping studies have been conducted on major medical journals to investigate the most common subjects, most productive scientists and countries, most prolific journals and "citation classics" across multiple specialties.

The objective of this study was to describe and characterise the global clinical research publication activity through RCT articles published in high-IF medical journals during the past decades.

\section{Methods}

\section{Eligibility criteria}

This cross-sectional analysis investigated RCT-related articles (that is, primary RCTs, secondary analyses and methodology papers using clinical data) published in major medical journals. We excluded narrative reviews, systematic reviews, meta-analyses, pool-analyses, letters and newspaper articles. All RCT-related articles indexed in PubMed/MEDLINE had to be published in one of the major medical journals with an IF exceeding 10 (2016 IF according to the Journal Citation Reports [JCR] published in June 2017). These medical journals were chosen because they were identified as publishing clinical research with scientific merit and clinical relevance (see Table 1 for a list of the included medical journals).

\section{Search}

On March 22, 2018, we systematically searched MEDLINE through PubMed (National Library of Medicine, Bethesda, MD, United States) for all RCT-related articles published in high-IF medical journals (from inception to December 31, 2017). A senior information specialist (AA-A) and a clinical epidemiologist (FC-L) designed an electronic literature search using a validated research methodology filter for RCTs (with 97\% specificity and 93\% sensitivity) [29]. The search was peer reviewed by members of the study team, including a second (senior) information specialist (RA-B). The full search strategy is provided in Additional file 1. On May 7, 2018, we searched the Web of Science (WoS) (Clarivate Analytics, Philadelphia, Penn., United States) by using PubMed IDs (PMIDs) from the PubMed/MEDLINE searches. Merging MEDLINE with other citation indices such as the WoS combines the advantages of MEDLINE (e.g., Medical Subject Headings [MeSH], a comprehensive controlled vocabulary for indexing journal articles) with the relational capabilities and data of the WoS [30].

\section{Data extraction and normalisation}

For each included article, raw (meta) data on the journal and article titles, subject category, the year of publication, keywords, and the authors' names, institutional affiliation(s), funding source, and country was downloaded online through the WoS by one researcher (AAA). We also used the WoS to determine the extent to which each article had been cited in the scientific peerreview literature using the "times cited" number (that is, the number of times a publication has been cited by other publications). Two researchers (FC-L, RA-B) independently verified the data to minimise potential 
Table 1 Included high-impact-factor medical journals

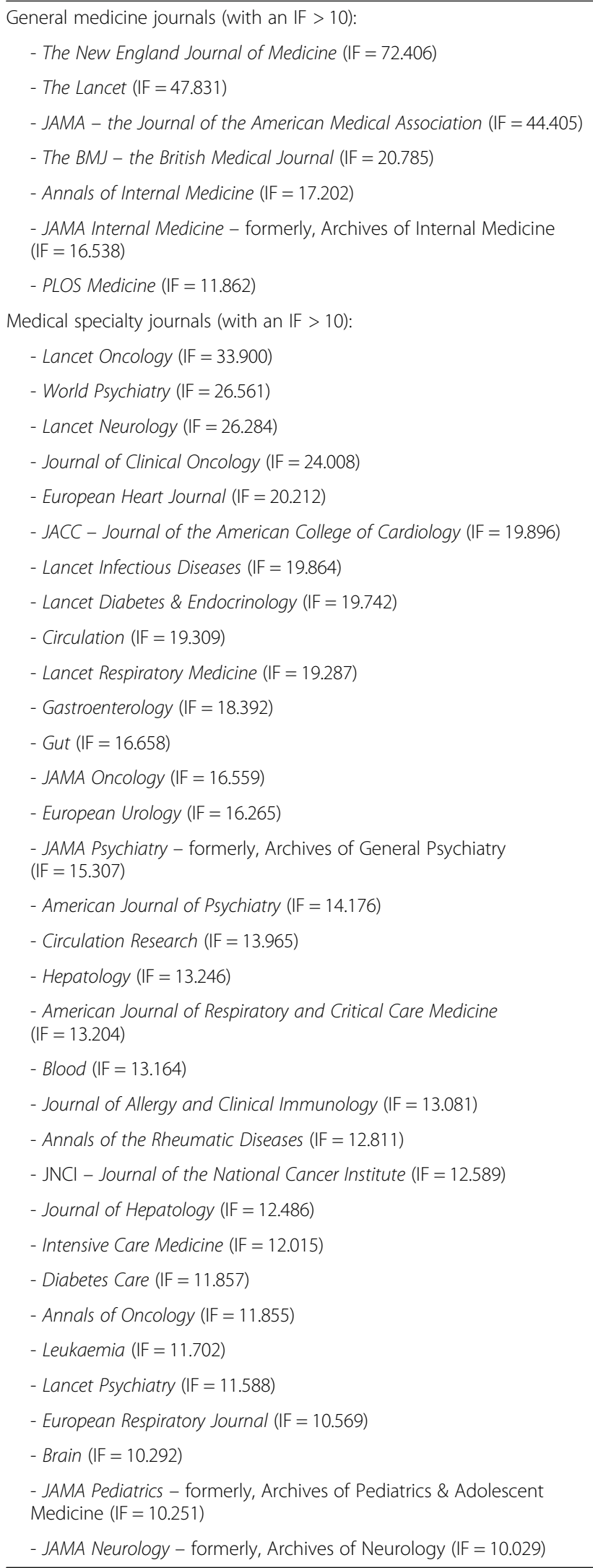

information errors. A process of normalisation was conducted by two researchers to bring together the different names of an author or country and the keywords (further details are available in Additional file 2). Specifically, one researcher (AA-A) checked the names by which an individual author appeared in two or more different forms (for example, "John McMurray" or "John J. McMurray" or "John J.V. McMurray") using coincidence in that author's place(s) of work as the basic criterion for normalisation (for example, University of Glasgow, Scotland, United Kingdom) [31], and a second researcher (FC-L or RA-B) verified the data. A threshold of 30 articles was applied to review 200 names by which an individual author appeared in two or more different forms.

We extracted both "author keywords" and "keyword plus," which are automatically assigned by the WoS from the titles of the references of the articles, as topical (also called textural, linguistic or sematic) data [32]. To ensure consistency in the data, one researcher (RA-B) corrected keywords by unifying grammatical variants and using only one keyword developed to name the same concept (for example, "randomized trial" or "randomized clinical trial" or "randomized controlled trial" or "randomised controlled trial"). In addition, the same researcher (RA-B) removed typographical, transcription and/or indexing errors, and a second researcher (FC-L) verified the data. All potential discrepancies were resolved via consensus amongst these investigators. All these data were collected and entered into a Microsoft Access ${ }^{\circ}$ (Microsoft, Seattle, WA, United States) database between May 7, 2018, and January 9, 2019.

\section{Data analysis}

We analysed data for the number of articles, citations, signatures (or total number of authors included in all the articles of each author), collaboration index (that is the mean number of author's signatures per article), countries, journals and keywords. Data were summarised as frequencies and percentages for the categorical items. The most prolific authors ( $>100$ articles), countries ( $>100$ articles), funding institutions ( $>100$ articles), and the most cited papers ("top-100 citation classics") were identified. Network plots were generated for intense scientific collaboration between countries (applying a threshold of 100 articles in collaboration).

We conducted an exploratory analyses of topical data using a set of unique keywords and their frequencies to examine the topic coverage, major topics ("word clouds" of keywords) and their interrelations ("co-words networks") in RCT articles. The main goal in topical analyses is to understand the topical distribution of a dataset, i.e. what topics are covered and how much of each topic is covered in a scientific discipline [32]. The 
most frequently used keywords were identified for the most prolific journals (with at least 1000 articles). Based on the most frequently used keywords (with at least 500 articles), a word cloud was created from text that the user provides and more emphasis was placed on words that appear with greater frequency in the source text. A "co-words network" was created to illustrate the cooccurrence of highly frequent words in the articles (applying a threshold of 100 articles in collaboration). The network analysis was carried out with the use of PAJEK (University of Ljubljana, Slovenia) [33], a software package for large network analysis that is free for noncommercial use to construct network graphs. The PRISMA checklist [34] (http://www.prisma-statement.org/) guided the reporting of the present analysis (and is available in Additional file 3).

\section{Results}

A total of 39,329 records were identified by the PubMed/MEDLINE search (Fig. 1), and 39,305 articles met the study inclusion criteria (Additional file 4) after 24 records had been excluded (Additional file 5). Table 2 details the general characteristics of the articles.

\section{Publication trend}

The number of articles increased exponentially over the period 1965-2017 (Fig. 2). Approximately 60\% $(n=23$, 635 ) of the articles have been published since 2000.

\section{Journals and subject category}

Forty journals published 39,305 articles, and 23.8\% of them $(n=9355)$ were published by four journals with an IF > 30. The Lancet $(9.1 \% ; n=3593)$, the Journal of Clinical Oncology $(8.5 \% ; n=3343)$ and The New England Journal of Medicine $(8.3 \% ; n=3275)$ published the largest number of articles, followed by The BMJ $(6.4 \% ; n=$ 2516) and Circulation (5.9\%; $n=2331$ ). Most articles were classified as "medicine, general \& internal" (30.7\%; $n=13,688)$; "cardiac \& cardiovascular systems" (13.1\%; $n=5828)$; or "oncology" (12.9\%; $n=5760)$ according to the WoS journal categorisations (Table 2).

\section{Authors, institutions and countries}

Most articles $(62.3 \% ; n=24,496)$ were written by seven or more authors, and only $11.4 \%(n=4469)$ of the articles were written by three or fewer authors. The first authors of the articles were based most commonly in North America and Western Europe; first authors from the United States were responsible for $36.9 \%(n=14$, 508) of the articles (Table 2). We identified 17 authors who published 100 or more articles (Table 3). All of the most productive authors were male. The most prolific authors were Robert M. Califf, with 239 articles (from Duke University, United States); Eugene Braunwald, with 218 (from Harvard University, United States); Salim Yusuf, with 217 (from McMaster University, Canada); Eric J. Topol, with 212 (from Scripps Translational

\section{Records retrieved through PubMed/MEDLINE search ( $\mathrm{n}=39329)$}

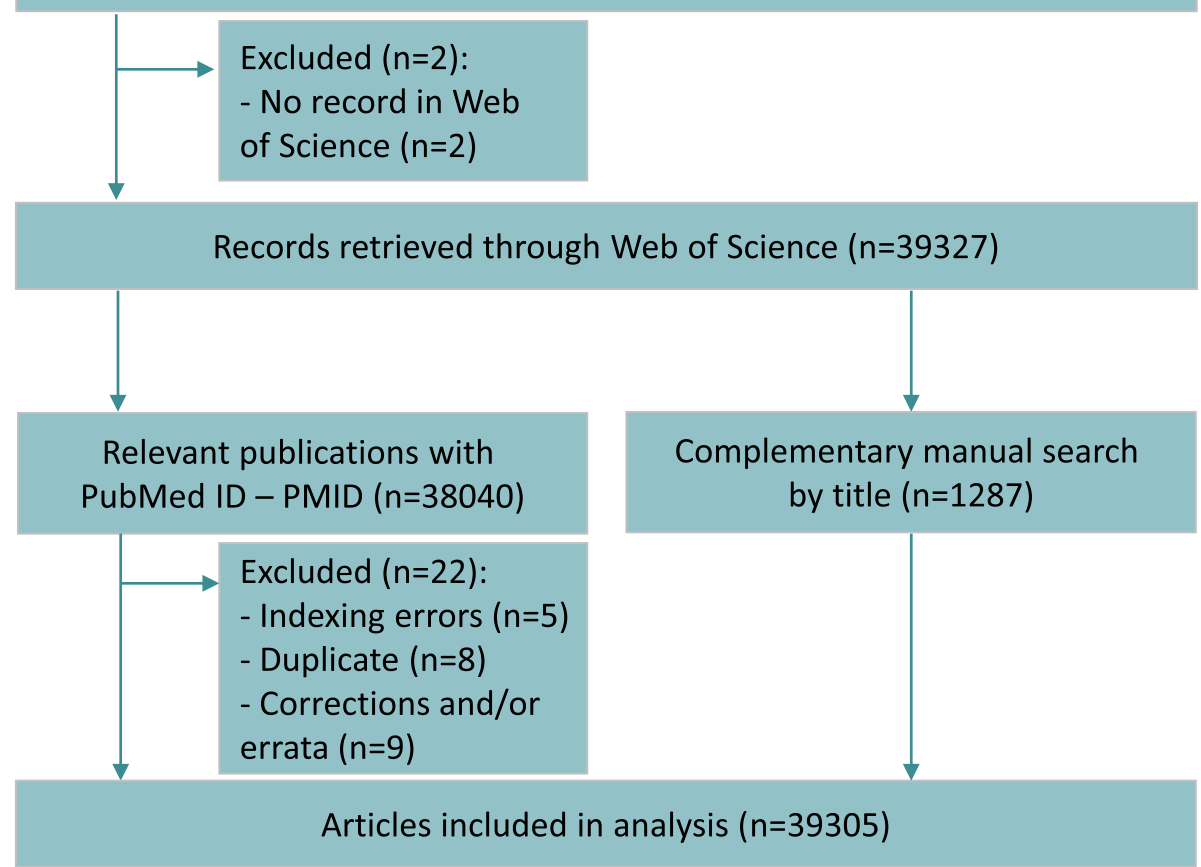

Fig. 1 Flow diagram with selection of articles 
Table 2 General characteristics of the study sample

\begin{tabular}{|c|c|c|}
\hline Characteristic & Number & Percent \\
\hline Total number of articles & 39,305 & 100.0 \\
\hline \multicolumn{3}{|l|}{ Journal (top-10) } \\
\hline The Lancet & 3593 & 9.1 \\
\hline Journal of Clinical Oncology & 3343 & 8.5 \\
\hline The New England Journal of Medicine & 3275 & 8.3 \\
\hline The BMJ & 2516 & 6.4 \\
\hline Circulation & 2331 & 5.9 \\
\hline JACC Journal of the American College of Cardiology & 2133 & 5.4 \\
\hline JAMA & 1904 & 4.8 \\
\hline Diabetes Care & 1885 & 4.8 \\
\hline Journal of Allergy and Clinical Immunology & 1345 & 3.4 \\
\hline European Heart Journal & 1315 & 3.3 \\
\hline \multicolumn{3}{|l|}{ Year of publication } \\
\hline Before 1980 & 2004 & 5.1 \\
\hline 1980-1989 & 4040 & 10.3 \\
\hline 1990-1999 & 9626 & 24.5 \\
\hline 2000-2009 & 12,574 & 32.0 \\
\hline 2010-2017 & 11,061 & 28.1 \\
\hline \multicolumn{3}{|l|}{ Journal impact factor (2016) } \\
\hline $10.0-15.0$ & 12,150 & 30.9 \\
\hline $15.1-20.0$ & 10,388 & 26.4 \\
\hline $20.1-25.0$ & 7174 & 18.3 \\
\hline $25.1-30.0$ & 238 & 0.6 \\
\hline$>30.0$ & 9355 & 23.8 \\
\hline \multicolumn{3}{|l|}{ Main subject category ${ }^{a}$} \\
\hline Medicine, General \& Internal & 13,688 & 30.7 \\
\hline Cardiac \& Cardiovascular Systems & 5828 & 13.1 \\
\hline Oncology & 5760 & 12.9 \\
\hline Gastroenterology \& Hepatology & 3023 & 6.8 \\
\hline Psychiatry & 2380 & 5.3 \\
\hline \multicolumn{3}{|l|}{ Number of citations } \\
\hline $0-50$ & 15,449 & 39.3 \\
\hline $51-100$ & 8714 & 22.2 \\
\hline $101-500$ & 13,056 & 33.2 \\
\hline $501-1000$ & 1445 & 3.7 \\
\hline$>1000$ & 641 & 1.6 \\
\hline \multicolumn{3}{|l|}{ Number of authors } \\
\hline 1 & 1064 & 2.7 \\
\hline $2-3$ & 3405 & 8.7 \\
\hline $4-6$ & 10,340 & 26.3 \\
\hline $7-10$ & 11,142 & 28.3 \\
\hline$>10$ & 13,354 & 34.0 \\
\hline \multicolumn{3}{|l|}{ Country of first author (top-10) } \\
\hline United States & 14,508 & 36.9 \\
\hline
\end{tabular}


Table 2 General characteristics of the study sample (Continued)

\begin{tabular}{lll}
\hline Characteristic & Number & Percent \\
\hline United Kingdom & 4924 & 12.5 \\
The Netherlands & 1874 & 4.8 \\
Germany & 1862 & 4.7 \\
Canada & 1847 & 4.7 \\
France & 1732 & 4.4 \\
Italy & 1720 & 4.4 \\
Australia & 999 & 2.5 \\
Sweden & 755 & 1.9 \\
Denmark & 660 & 1.7 \\
Source of funding & & 41.9 \\
Reported & 16,485 & 58.1 \\
None/not reported & 22,820 & \\
\hline
\end{tabular}

${ }^{\text {aSubject category according to Journal Citation Reports (JCR) }}$

Science Institute, United States); Harvey D. White, with 186 (from University of Auckland, New Zealand); Lars Wallentin, with 144 (Uppsala University, Sweden); and Christopher B. Granger, with 140 (from Duke University, United States).

Overall, 154 countries worldwide contributed to the analysed articles. The publication productivity ranking for countries (Table 4) was led by the United States $(n=$ 18,393 articles, with 3.4 million citations), followed by the United Kingdom $(n=8028$ articles, with 1.3 million citations), Canada ( $n=4548$ articles, with 1.0 million citations) and Germany ( $n=4415$ articles, with 0.9 million citations). A total of 37 countries had at least 100 articles in co-authorship. Figure 3 shows a visual representation of the most intense collaborative network between these 37 countries, in which we can see the relationships of some countries with respect to others and the position that each occupies in the network.

\section{Funding source}

A total of 16,485 articles (41.9\%) reported sources of funding. The 40 most frequent funding institutions (with 100 or more articles) are listed in Table 5. The main funders were the National Institutes of Health $(\mathrm{NIH})$, with 7422 articles; Hoffmann-La Roche $(n=1188)$, Pfizer $(n=1139)$, Merck Sharp \& Dohme $(n=1097)$ and Novartis $(n=1052)$.

\section{Most cited articles}

Overall, included articles received 5.9 million citations, of which $83.1 \%$ of the citations $(n=4,950,604)$ corresponded to $15,142(38.5 \%)$ articles with more than 100

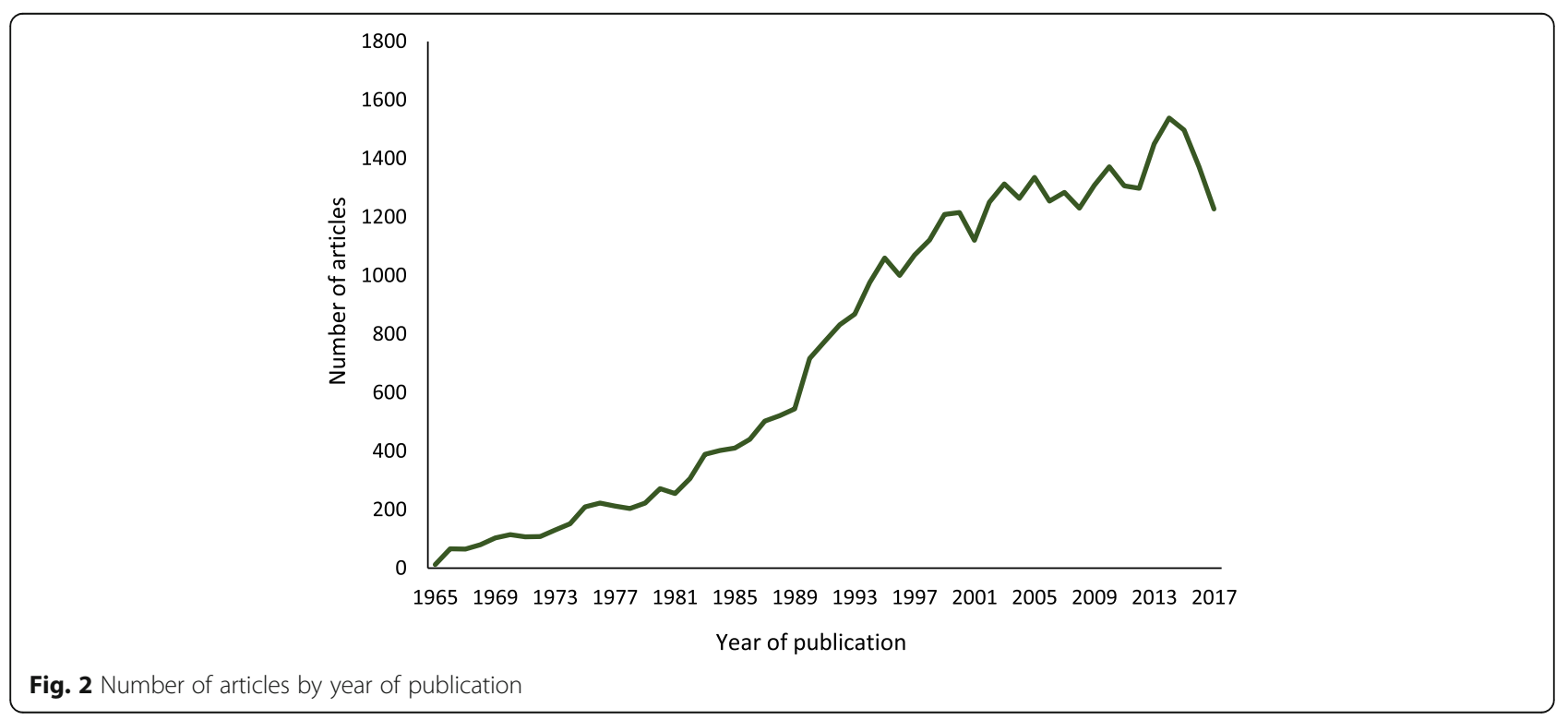


Table 3 Most productive authors and their institutions

\begin{tabular}{|c|c|c|c|c|c|c|c|}
\hline Author & Affiliation and country & Articles & Citations & $\begin{array}{l}\text { Citations } \\
\text { per article }\end{array}$ & $\begin{array}{l}\text { Articles in } \\
\text { collaboration }\end{array}$ & $\begin{array}{l}\text { Total } \\
\text { signatures }\end{array}$ & $\begin{array}{l}\text { Collaboration index } \\
\text { (signatures per article) }\end{array}$ \\
\hline Califf, Robert M. & $\begin{array}{l}\text { Duke Clinical Research Institute, Duke } \\
\text { University, United States }\end{array}$ & 239 & 56,742 & 237.4 & 239 & 7919 & 33.1 \\
\hline Braunwald, Eugene & $\begin{array}{l}\text { Brigham and Women's Hospital, } \\
\text { Harvard University, United States }\end{array}$ & 218 & 63,764 & 292.5 & 218 & 8296 & 38.1 \\
\hline Yusuf, Salim & McMaster University, Canada & 217 & 79,270 & 365.3 & 216 & 9163 & 42.4 \\
\hline Topol, Eric J. & $\begin{array}{l}\text { Scripps Translational Science Institute, } \\
\text { United States }\end{array}$ & 212 & 48,523 & 228.9 & 212 & 6229 & 29.4 \\
\hline White, Harvey D. & $\begin{array}{l}\text { Auckland City Hospital, University of } \\
\text { Auckland, New Zealand }\end{array}$ & 186 & 38,540 & 207.2 & 185 & 9133 & 49.4 \\
\hline Wallentin, Lars & $\begin{array}{l}\text { Uppsala Clinical Research Centre, } \\
\text { Uppsala University, Sweden }\end{array}$ & 144 & 32,741 & 227.4 & 142 & 2958 & 20.8 \\
\hline Granger, Christopher B. & $\begin{array}{l}\text { Duke Clinical Research Institute, Duke } \\
\text { University, United States }\end{array}$ & 140 & 29,668 & 211.9 & 140 & 5025 & 35.9 \\
\hline Stone, Gregg W. & $\begin{array}{l}\text { New York-Presbyterian Hospital, } \\
\text { Columbia University, United States }\end{array}$ & 135 & 24,601 & 182.2 & 135 & 1928 & 14.3 \\
\hline Serruys, Patrick W. & $\begin{array}{l}\text { Imperial College London, United } \\
\text { Kingdom and } \\
\text { Erasmus University, The Netherlands }\end{array}$ & 133 & 27,302 & 205.3 & 133 & 2253 & 16.9 \\
\hline Armstrong, Paul W. & $\begin{array}{l}\text { University of Alberta Hospital, } \\
\text { University of Alberta, Canada }\end{array}$ & 125 & 25,992 & 207.9 & 124 & 4573 & 36.9 \\
\hline McMurray, John J.V. & $\begin{array}{l}\text { University of Glasgow, Scotland, } \\
\text { United Kingdom }\end{array}$ & 116 & 30,470 & 262.7 & 116 & 3425 & 29.5 \\
\hline Pfeffer, Marc A. & $\begin{array}{l}\text { Brigham and Women's Hospital, } \\
\text { Harvard University, United States }\end{array}$ & 116 & 46,032 & 396.8 & 115 & 4070 & 35.4 \\
\hline Gelber, Richard D. & $\begin{array}{l}\text { Dana-Farber Cancer Institute, Harvard } \\
\text { University, United States }\end{array}$ & 107 & 20,898 & 195.3 & 107 & 3311 & 30.9 \\
\hline Van de Werf, Frans & $\begin{array}{l}\text { Catholic University of Leuven, } \\
\text { University Hospital Leuven, Belgium }\end{array}$ & 107 & 21,918 & 204.8 & 105 & 4492 & 42.8 \\
\hline Harrington, Robert A. & Stanford University, United States & 105 & 20,436 & 194.6 & 103 & 4971 & 48.3 \\
\hline Cannon, Christopher P. & $\begin{array}{l}\text { Brigham and Women's Hospital, } \\
\text { Harvard University, United States }\end{array}$ & 103 & 26,192 & 254.3 & 103 & 2241 & 21.8 \\
\hline Goldhirsch, Aron & European Institute of Oncology, Italy & 103 & 16,254 & 157.8 & 98 & 3279 & 33.5 \\
\hline
\end{tabular}

Note: Top authors with at least 100 articles

citations. In addition, $641(1.63 \%)$ articles with more than 1000 citations accounted for $20.7 \%$ of the total citations $(n=1,234,462)$. The most cited articles by number of citations ("100 citation classics") are listed in Table 6. All of the most cited papers were published in English. These most cited articles were published in nine journals, led by The New England Journal of Medicine, with 78 articles, followed by The Lancet $(n=9)$ and JAMA $(n=7)$. The list of most cited papers contained innovative research methodologies. For example, the most cited article was a method paper published in The Lancet ("Bland-Altman method") [35]. This seminal paper changed how method comparison studies are performed in clinical research. The list of the most cited papers also reflected important studies examining the health effects of pharmacological interventions on patients with chronic diseases. Common themes in major advances in health interventions included diabetes control [36-41]; the effects of hormone replacement therapy in postmenopausal women [42, 43]; therapies for diverse cancers such as glioblastoma, colorectal cancer, breast cancer, melanoma and hepatocellular carcinoma [44-50]; important interventional studies in the field of clinical cardiology, such as lipid-lowering statin therapy trials, antihypertensive trials, and antiplatelet and/or antithrombotic trials [51-63].

\section{Common keywords}

The most commonly used article keywords were "clinical trial" (16.1\%; $n=6332$ papers), followed by "therapy" $(10.8 \% ; n=4267)$, "randomised controlled trial" $(6.6 \%$; $n=2587)$, "chemotherapy" (5.6\%; $n=2224)$, "risk" (5.1\%; $n=2026)$, "efficacy" (4.9\%; $n=1933)$ and "double-blind" (4.9\%; $n=1929)$. The most frequently used keywords in the most prolific journals are shown in Table 7. In addition, exploratory analyses of word clouds and 
Table 4 Productivity and patterns of collaboration by top countries

\begin{tabular}{|c|c|c|c|c|c|c|c|c|}
\hline Country & $\begin{array}{l}\text { Total } \\
\text { articles }\end{array}$ & $\begin{array}{l}\text { Articles per } \\
\text { million } \\
\text { inhabitants }\end{array}$ & $\begin{array}{l}\text { Total } \\
\text { collaborations }\end{array}$ & $\begin{array}{l}\text { Total } \\
\text { citations }\end{array}$ & $\begin{array}{l}\text { Citations } \\
\text { per article }\end{array}$ & $\begin{array}{l}\text { Articles in } \\
\text { collaboration } \\
\text { (distinct country) }\end{array}$ & $\begin{array}{l}\text { Distinct } \\
\text { countries of } \\
\text { collaboration }\end{array}$ & $\begin{array}{l}\text { Main collaborator (and } \\
\text { number of } \\
\text { collaborations) }\end{array}$ \\
\hline United States & 18,393 & 56.5 & 25,308 & $3,364,015$ & 182.9 & 7895 & 130 & Canada (2892) \\
\hline United Kingdom & 8028 & 121.6 & 18,529 & $1,345,597$ & 167.6 & 4534 & 128 & United States (2528) \\
\hline Canada & 4548 & 123.9 & 13,024 & $1,017,912$ & 223.8 & 3552 & 108 & United States (2892) \\
\hline Germany & 4415 & 53.4 & 16,463 & 894,026 & 202.5 & 3416 & 111 & United States (2034) \\
\hline France & 3900 & 58.1 & 15,093 & 826,172 & 211.8 & 2928 & 119 & United States (1759) \\
\hline Italy & 3608 & 59.6 & 13,005 & 674,367 & 186.9 & 2432 & 96 & United States (1446) \\
\hline The Netherlands & 3453 & 201.5 & 10,578 & 619,589 & 179.4 & 2331 & 99 & United States (1172) \\
\hline Australia & 2354 & 95.7 & 8787 & 469,341 & 199.4 & 1750 & 103 & United States (1114) \\
\hline Belgium & 2197 & 193.2 & 10,685 & 482,974 & 219.8 & 2016 & 107 & United States (1068) \\
\hline Spain & 2020 & 43.4 & 9747 & 417,291 & 206.6 & 1581 & 99 & United States (1017) \\
\hline Sweden & 1909 & 189.6 & 7034 & 376,159 & 197.0 & 1483 & 91 & United States (794) \\
\hline Switzerland & 1862 & 219.9 & 7840 & 348,734 & 187.3 & 1621 & 117 & United States (818) \\
\hline Denmark & 1523 & 264.0 & 5572 & 297,936 & 195.6 & 1090 & 84 & United States (582) \\
\hline Poland & 953 & 25.1 & 6577 & 222,301 & 233.3 & 916 & 80 & United States (650) \\
\hline Austria & 945 & 107.3 & 4673 & 192,799 & 204.0 & 832 & 85 & Germany (555) \\
\hline Japan & 820 & 6.5 & 2232 & 132,758 & 161.9 & 374 & 66 & United States (289) \\
\hline Finland & 797 & 144.6 & 2950 & 195,500 & 245.3 & 556 & 81 & United States (264) \\
\hline China & 771 & 0.6 & 3292 & 141,741 & 183.8 & 550 & 87 & United States (391) \\
\hline Norway & 756 & 143.1 & 3076 & 152,184 & 201.3 & 605 & 70 & Sweden (310) \\
\hline Israel & 661 & 75.9 & 3364 & 159,264 & 240.9 & 547 & 71 & United States (382) \\
\hline Brazil & 626 & 3.0 & 4102 & 154,296 & 246.5 & 567 & 98 & United States (440) \\
\hline New Zealand & 602 & 125.6 & 2229 & 106,318 & 176.6 & 480 & 80 & United States (293) \\
\hline Czech Republic & 486 & 45.9 & 3757 & 107,543 & 221.3 & 475 & 82 & United States (315) \\
\hline South Korea & 474 & 9.2 & 2748 & 80,338 & 169.5 & 383 & 78 & United States (322) \\
\hline South Africa & 463 & 8.2 & 2468 & 89,382 & 193.0 & 422 & 95 & United States (311) \\
\hline Russia & 425 & 2.9 & 3449 & 109,224 & 257.0 & 424 & 75 & United States (336) \\
\hline Greece & 419 & 38.9 & 2114 & 59,496 & 142.0 & 285 & 75 & United States (168) \\
\hline Hungary & 392 & 40.1 & 3192 & 93,590 & 238.7 & 383 & 74 & United States (249) \\
\hline Argentina & 390 & 8.8 & 2736 & 117,289 & 300.7 & 357 & 91 & United States (290) \\
\hline India & 370 & 0.3 & 2016 & 63,646 & 172.0 & 299 & 101 & United States (214) \\
\hline Taiwan & 341 & 14.5 & 1803 & 77,089 & 226.1 & 242 & 63 & United States (194) \\
\hline Ireland & 297 & 61.7 & 1366 & 60,867 & 204.9 & 263 & 79 & United Kingdom (170) \\
\hline Mexico & 253 & 2.0 & 1754 & 56,256 & 222.4 & 230 & 84 & United States (195) \\
\hline Singapore & 194 & 34.6 & 1210 & 42,265 & 217.9 & 176 & 80 & United States (120) \\
\hline Turkey & 189 & 2.3 & 1288 & 34,928 & 184.8 & 149 & 79 & United States (92) \\
\hline Thailand & 185 & 2.7 & 1268 & 55,360 & 299.2 & 177 & 93 & United States (120) \\
\hline Portugal & 168 & 16.3 & 1218 & 24,177 & 143.9 & 160 & 61 & Belgium (89), France (89) \\
\hline Chile & 157 & 8.7 & 1265 & 37,556 & 239.2 & 149 & 81 & United States (112) \\
\hline Romania & 149 & 7.6 & 1406 & 31,392 & 210.7 & 148 & 77 & United States (110) \\
\hline Ukraine & 113 & 2.5 & 1007 & 29,880 & 264.4 & 113 & 61 & United States (84) \\
\hline Uganda & 112 & 2.6 & 405 & 14,931 & 133.3 & 108 & 72 & United States (78) \\
\hline Kenya & 107 & 2.2 & 508 & 18,737 & 175.1 & 103 & 83 & United States (68) \\
\hline
\end{tabular}

Note: Top countries with at least 100 articles. Country inhabitants (year 2017) obtained from the World Bank (http://data.worldbank.org/) 


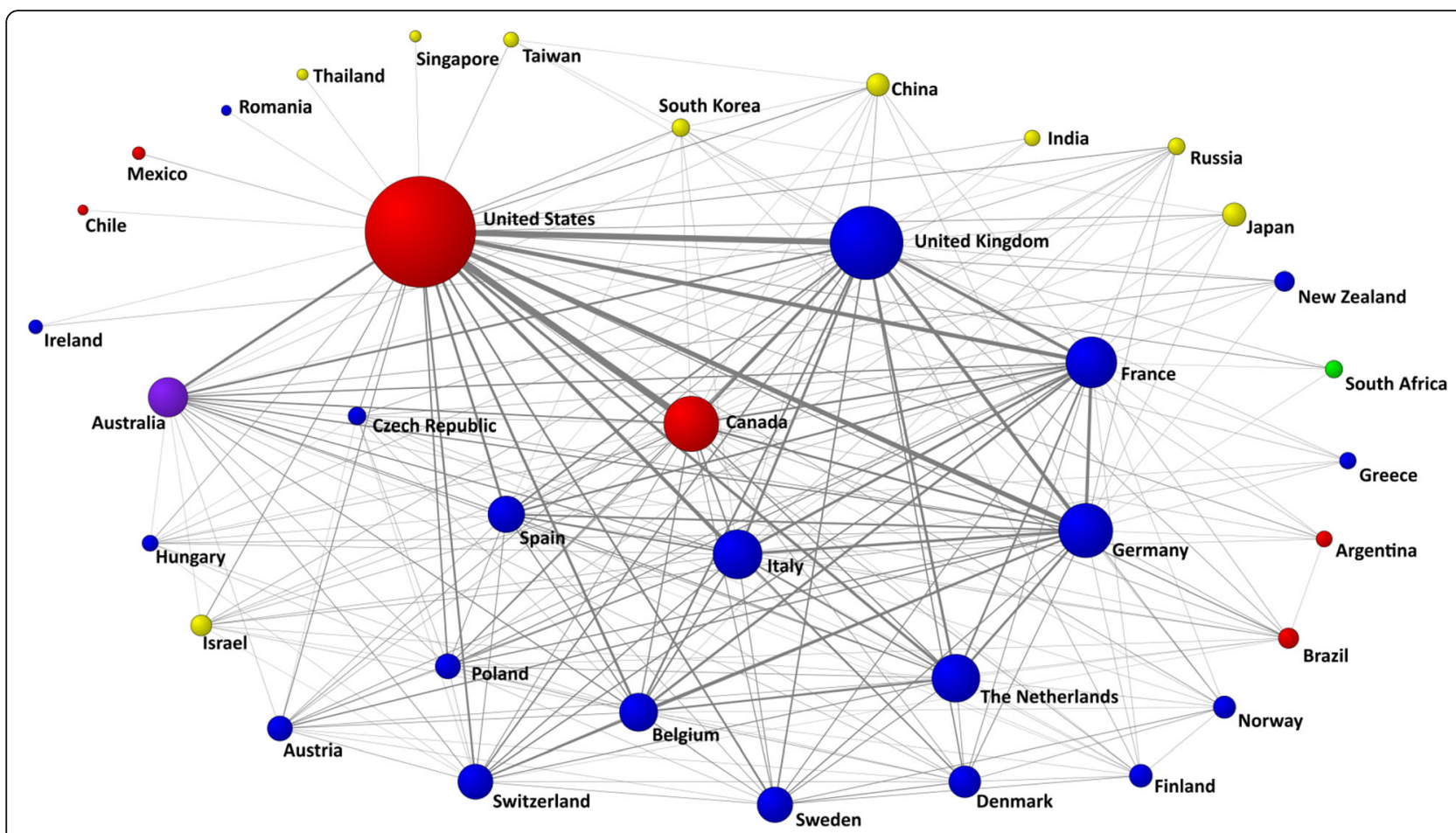

Fig. 3 Global collaborative network between countries. Note: Most productive cluster of countries applying a threshold of 100 or more papers signed in co-authorship. Node sizes are proportional to the number of papers, and line thicknesses are proportional to the number of collaborations. Node colours: America = red; Asia = yellow; Africa = green; Europe = blue; Oceania = purple

networks based on keywords (co-words) showed the broad range of the topics covered (see Additional file 6).

\section{Discussion}

In this cross-sectional analysis, we presented a global mapping of RCT-related articles published in high-IF medical journals for the period 1965-2017. We identified the most prolific scientists, institutions and countries, main funding sources, most common subjects and topics, "citation classics" and most prolific high-IF medical journals from multiple specialties over the last 50 years.

In general, we found a strong clustering of articles published in British and American medical journals (The Lancet, Journal of Clinical Oncology, The New England Journal of Medicine, The BMJ, Circulation, JAMA, JACC and Diabetes Care accounted for $53 \%$ of the RCTrelated articles). Many of these journals have been developed by active medical associations, both nationally and internationally. We hypothesize that different publishing patterns between journals may potentially reflect editorial policies and/or preferences, with some general medicine journals (such as The Lancet and The New England Journal of Medicine) and specialty journals (such as Journal of Clinical Oncology and Circulation), being more interested in and/or promoting the publication of RCTs. In contrast, a substantial number of these articles are behind publication paywalls (very few of the medical journals in our study sample are Open Access), and thus, research results may not be accessible to a large fraction of the scientific community and society as a whole, including clinicians (and patients) who may want them to help inform their clinical practice.

The results of this study highlight the expanding collaborative networks between countries in multiple regions, revealing a discernible scientific community, with the most productive countries having an important number of collaborations. Publication activity efforts were global during the study period, with articles from scientists and institutions in more than 150 different countries. However, the scientific community is centred on a nucleus of scientists from Western countries, with the most intense global collaborations taking place among the United States, United Kingdom and Canada. The presence and influence that these countries have on biomedical research [64-66] may be due to their large multi-stakeholder research partnerships, greater financial investment in clinical research, and high population of active scientists and research centres compared to other countries.

Publication activity worldwide shows that low- and middle-income countries have low levels of articles in high-IF medical journals. Difficulties in healthcare, education and research systems, information access and communication, language barriers and economic and 
Table 5 Most frequent funding institutions

\begin{tabular}{|c|c|c|c|c|c|c|c|}
\hline $\begin{array}{l}\text { Funding institution and } \\
\text { country }\end{array}$ & $\begin{array}{l}\text { Funding } \\
\text { type }\end{array}$ & Articles & Citations & $\begin{array}{l}\text { Citations } \\
\text { per } \\
\text { article }\end{array}$ & $\begin{array}{l}\text { Articles in } \\
\text { collaboration }\end{array}$ & Journals & Main journals (number of articles) \\
\hline $\begin{array}{l}\text { National Institutes of Health } \\
(\mathrm{NIH}) \text {, United States }\end{array}$ & Non-industry & 7422 & $1,312,297$ & 176.8 & 2187 & 39 & $\begin{array}{l}\text { Journal of Clinical Oncology (1096), The New } \\
\text { England Journal of Medicine (869), JAMA (614) }\end{array}$ \\
\hline $\begin{array}{l}\text { Hoffmann-La Roche, } \\
\text { Switzerland }\end{array}$ & Industry & 1188 & 218,428 & 183.9 & 997 & 36 & $\begin{array}{l}\text { The New England Journal of Medicine (159), } \\
\text { Journal of Clinical Oncology (155), Lancet } \\
\text { Oncology (96) }\end{array}$ \\
\hline Pfizer, Inc., United States & Industry & 1139 & 197,275 & 173.2 & 1001 & 36 & $\begin{array}{l}\text { The New England Journal of Medicine (187), } \\
\text { JACC (112), Journal of Clinical Oncology (82) }\end{array}$ \\
\hline $\begin{array}{l}\text { Merck Sharp \& Dohme } \\
\text { (MSD), United States }\end{array}$ & Industry & 1097 & 189,047 & 172.3 & 978 & 35 & $\begin{array}{l}\text { The New England Journal of Medicine (156), } \\
\text { JACC (145), Diabetes Care (116) }\end{array}$ \\
\hline Novartis, Switzerland & Industry & 1052 & 192,229 & 182.7 & 900 & 34 & $\begin{array}{l}\text { The New England Journal of Medicine (157), } \\
\text { JACC (107), Journal of Clinical Oncology (81) }\end{array}$ \\
\hline Sanofi, France & Industry & 987 & 170,078 & 172.3 & 920 & 34 & $\begin{array}{l}\text { JACC (152), Diabetes Care (142), The New } \\
\text { England Journal of Medicine (135) }\end{array}$ \\
\hline $\begin{array}{l}\text { AstraZeneca, United } \\
\text { Kingdom }\end{array}$ & Industry & 938 & 168,667 & 179.8 & 841 & 33 & $\begin{array}{l}\text { JACC (166), The New England Journal of } \\
\text { Medicine (131), Diabetes Care (101) }\end{array}$ \\
\hline $\begin{array}{l}\text { GlaxoSmithKline, United } \\
\text { Kingdom }\end{array}$ & Industry & 937 & 174,377 & 186.1 & 832 & 35 & $\begin{array}{l}\text { The New England Journal of Medicine (154), } \\
\text { JACC (95), Diabetes Care (88) }\end{array}$ \\
\hline $\begin{array}{l}\text { Bristol-Myers Squibb (BMS), } \\
\text { United States }\end{array}$ & Industry & 924 & 186,731 & 202.1 & 843 & 33 & $\begin{array}{l}\text { The New England Journal of Medicine (141), } \\
\text { JACC (121), Diabetes Care (119) }\end{array}$ \\
\hline $\begin{array}{l}\text { Johnson \& Johnson, } \\
\text { United States }\end{array}$ & Industry & 873 & 153,063 & 175.3 & 791 & 34 & $\begin{array}{l}\text { The New England Journal of Medicine (136), } \\
\text { JACC (113), Diabetes Care (90) }\end{array}$ \\
\hline $\begin{array}{l}\text { Abbott Laboratories, } \\
\text { United States }\end{array}$ & Industry & 843 & 141,475 & 167.8 & 758 & 33 & $\begin{array}{l}\text { JACC (218), The New England Journal of } \\
\text { Medicine (129), Diabetes Care (71) }\end{array}$ \\
\hline $\begin{array}{l}\text { Eli Lilly and Company, } \\
\text { United States }\end{array}$ & Industry & 796 & 118,087 & 148.4 & 727 & 29 & $\begin{array}{l}\text { Diabetes Care (144), JACC (133), The New } \\
\text { England Journal of Medicine (88) }\end{array}$ \\
\hline $\begin{array}{l}\text { Boehringer Ingelheim, } \\
\text { Germany }\end{array}$ & Industry & 600 & 125,626 & 209.4 & 537 & 31 & $\begin{array}{l}\text { The New England Journal of Medicine (115), } \\
\text { Diabetes Care (89), JACC (78) }\end{array}$ \\
\hline Medtronic, United States & Industry & 565 & 95,746 & 169.5 & 525 & 25 & $\begin{array}{l}\text { JACC (186), The New England Journal of } \\
\text { Medicine (84), Diabetes Care (65) }\end{array}$ \\
\hline $\begin{array}{l}\text { National Institute of } \\
\text { Health Research (NIHR), } \\
\text { United Kingdom }\end{array}$ & Non-industry & 502 & 42,358 & 84.4 & 409 & 40 & $\begin{array}{l}\text { The Lancet (76), The BMJ (66), The New England } \\
\text { Journal of Medicine (35) }\end{array}$ \\
\hline Amgen Inc., United States & Industry & 488 & 83,923 & 172.0 & 424 & 25 & $\begin{array}{l}\text { The New England Journal of Medicine (88), } \\
\text { Journal of Clinical Oncology (65), JACC (64) }\end{array}$ \\
\hline Bayer AG, Germany & Industry & 487 & 107,327 & 220.4 & 453 & 33 & $\begin{array}{l}\text { The New England Journal of Medicine (89), JACC } \\
\text { (84), Circulation (42) }\end{array}$ \\
\hline $\begin{array}{l}\text { Medical Research Council } \\
\text { (MRC), United Kingdom }\end{array}$ & Non-industry & 426 & 67,256 & 157.9 & 304 & 39 & $\begin{array}{l}\text { The Lancet (84), The BMJ (47), The New England } \\
\text { Journal of Medicine (29) }\end{array}$ \\
\hline $\begin{array}{l}\text { Takeda Pharmaceutical } \\
\text { Company, Japan }\end{array}$ & Industry & 392 & 83,259 & 212.4 & 354 & 28 & $\begin{array}{l}\text { Diabetes Care (71), The New England Journal of } \\
\text { Medicine (70), JACC (44) }\end{array}$ \\
\hline $\begin{array}{l}\text { National Health and } \\
\text { Medical Research } \\
\text { Council (NHMRC), Australia }\end{array}$ & Non-industry & 338 & 35,116 & 103.9 & 276 & 38 & $\begin{array}{l}\text { Diabetes Care (34), The New England Journal of } \\
\text { Medicine (34), The Lancet (34) }\end{array}$ \\
\hline $\begin{array}{l}\text { Daiichi Sankyo Company, } \\
\text { Japan }\end{array}$ & Industry & 336 & 52,054 & 154.9 & 325 & 18 & $\begin{array}{l}\text { JACC (105), Diabetes Care (46), The New England } \\
\text { Journal of Medicine (43) }\end{array}$ \\
\hline $\begin{array}{l}\text { Boston Scientific } \\
\text { Corporation, United States }\end{array}$ & Industry & 317 & 45,609 & 143.9 & 291 & 14 & $\begin{array}{l}\text { JACC (140), Circulation (58), European Heart } \\
\text { Journal (38) }\end{array}$ \\
\hline Novo Nordisk, Denmark & Industry & 306 & 44,994 & 147.0 & 273 & 26 & $\begin{array}{l}\text { Diabetes Care (162), The New England Journal of } \\
\text { Medicine (38), The Lancet (24) }\end{array}$ \\
\hline $\begin{array}{l}\text { Gilead Sciences, } \\
\text { United States }\end{array}$ & Industry & 301 & 53,978 & 179.3 & 244 & 22 & $\begin{array}{l}\text { The New England Journal of Medicine (67), } \\
\text { JACC (49), Hepatology (26) }\end{array}$ \\
\hline $\begin{array}{l}\text { Wellcome Trust, } \\
\text { United Kingdom }\end{array}$ & Non-industry & 276 & 32,785 & 118.8 & 142 & 36 & $\begin{array}{l}\text { The Lancet (67), The BMJ (34), } \\
\text { PLOS Medicine (26) }\end{array}$ \\
\hline
\end{tabular}


Table 5 Most frequent funding institutions (Continued)

\begin{tabular}{|c|c|c|c|c|c|c|c|}
\hline $\begin{array}{l}\text { Funding institution and } \\
\text { country }\end{array}$ & $\begin{array}{l}\text { Funding } \\
\text { type }\end{array}$ & Articles & Citations & $\begin{array}{l}\text { Citations } \\
\text { per } \\
\text { article }\end{array}$ & $\begin{array}{l}\text { Articles in } \\
\text { collaboration }\end{array}$ & Journals & Main journals (number of articles) \\
\hline $\begin{array}{l}\text { Canadian Institutes of } \\
\text { Health Research (CIHR), } \\
\text { Canada }\end{array}$ & Non-industry & 266 & 27,300 & 102.6 & 216 & 30 & $\begin{array}{l}\text { The New England Journal of Medicine (46), JAMA } \\
\text { (29), The Lancet (22) }\end{array}$ \\
\hline $\begin{array}{l}\text { Cancer Research UK, } \\
\text { United Kingdom }\end{array}$ & Non-industry & 229 & 23,766 & 103.8 & 202 & 21 & $\begin{array}{l}\text { Lancet Oncology (64), Journal of Clinical } \\
\text { Oncology (45), Annals of Oncology (27) }\end{array}$ \\
\hline Allergan plc, Ireland & Industry & 203 & 32,028 & 157.8 & 195 & 26 & $\begin{array}{l}\text { American Journal of Psychiatry (39), The New } \\
\text { England Journal of Medicine (27), JACC (18) }\end{array}$ \\
\hline Servier, France & Industry & 199 & 33,106 & 166.4 & 194 & 20 & $\begin{array}{l}\text { JACC (51), The New England Journal of Medicine } \\
\text { (29), European Heart Journal (24) }\end{array}$ \\
\hline Astellas Pharma Inc., Japan & Industry & 193 & 38,282 & 198.4 & 178 & 29 & $\begin{array}{l}\text { The New England Journal of Medicine (38), } \\
\text { European Urology (18), JACC (16) }\end{array}$ \\
\hline $\begin{array}{l}\text { Teva Pharmaceutical } \\
\text { Industries Ltd., Israel }\end{array}$ & Industry & 175 & 29,128 & 166.4 & 167 & 24 & $\begin{array}{l}\text { The New England Journal of Medicine (29), } \\
\text { Lancet Neurology (20), Journal of Allergy and } \\
\text { Clinical Immunology (18) }\end{array}$ \\
\hline $\begin{array}{l}\text { The Medicines Company, } \\
\text { United States }\end{array}$ & Industry & 175 & 26,314 & 150.4 & 165 & 10 & $\begin{array}{l}\text { JACC (76), Circulation (29), The New England } \\
\text { Journal of Medicine (28) }\end{array}$ \\
\hline Eisai Co., Ltd., Japan & Industry & 161 & 36,321 & 225.6 & 150 & 22 & $\begin{array}{l}\text { The New England Journal of Medicine (34), } \\
\text { JACC (30), Circulation (16) }\end{array}$ \\
\hline Merck KGaA, Germany & Industry & 156 & 35,146 & 225.3 & 134 & 20 & $\begin{array}{l}\text { The New England Journal of Medicine (24), } \\
\text { Annals of Oncology (21), Lancet Oncology (20) }\end{array}$ \\
\hline $\begin{array}{l}\text { Otsuka Pharmaceutical } \\
\text { Co., Ltd., Japan }\end{array}$ & Industry & 138 & 21,029 & 152.4 & 130 & 20 & $\begin{array}{l}\text { JACC (31), American Journal of Psychiatry (31), } \\
\text { The New England Journal of Medicine (14) }\end{array}$ \\
\hline $\begin{array}{l}\text { Bill \& Melinda Gates } \\
\text { Foundation, United States }\end{array}$ & Non-industry & 135 & 15,839 & 117.3 & 95 & 15 & $\begin{array}{l}\text { The Lancet (33), PLOS Medicine (27), The New } \\
\text { England Journal of Medicine (24) }\end{array}$ \\
\hline $\begin{array}{l}\text { Celgene Corporation, } \\
\text { United States }\end{array}$ & Industry & 134 & 26,369 & 196.8 & 102 & 19 & $\begin{array}{l}\text { Journal of Clinical Oncology (31), The New } \\
\text { England Journal of Medicine (26), Blood (20) }\end{array}$ \\
\hline $\begin{array}{l}\text { Federal Ministry of } \\
\text { Education and Research } \\
\text { (BMBF), Germany }\end{array}$ & Non-industry & 119 & 11,409 & 95.9 & 104 & 28 & $\begin{array}{l}\text { Journal of Clinical Oncology (14), Blood (10), } \\
\text { Diabetes Care (9) }\end{array}$ \\
\hline UCB, Belgium & Industry & 118 & 16,085 & 136.3 & 100 & 14 & $\begin{array}{l}\text { Annals of the Rheumatic Diseases (47), Lancet } \\
\text { Neurology (14), The New England Journal of } \\
\text { Medicine (13) }\end{array}$ \\
\hline Biotronik, Germany & Industry & 104 & 15,554 & 149.6 & 96 & 7 & $\begin{array}{l}\text { JACC (44), European Heart Journal (22), The New } \\
\text { England Journal of Medicine (19) }\end{array}$ \\
\hline
\end{tabular}

institutional instability all represent challenges (and clear disadvantages) for productivity in low- and middleincome regions. In addition, restrictions and difficulties in conducting clinical research in resource-poor situations result in the exclusion of many of these countries from the planning, conduct and publication of RCTs [67-69]. As might be expected, our results support previous findings that low- and middle-income countries [31, 70, 71] had minimal contributions in articles published in major medical journals. For example, a previous study [70] showed that most of the authors of original papers published in five high-impact general medical journals (including The New England Journal of Medicine, The Lancet, JAMA, The BMJ and Annals of Internal Medicine) were more frequently affiliated with institutions in the same country as the journal. To address some of these problems, scientists, institutions and funders should promote collaborations (beyond historical, cultural and political factors) to share knowledge, expertise and innovative methodologies for clinical research. This may involve partnerships with Western countries to support capacity and resource development and research training.

RCT-related articles were published most often in high IF medical journals devoted to general and internal medicine, cardiology and oncology (nearly $57 \%$ of all articles). Similarly, the lists of the most cited articles identified topics which reflect major advances in the management of chronic conditions (such diabetes, cardiovascular disorders and cancer). The large relative productivity in general internal medicine, cardiology and oncology may be explained by the important role of randomised evidence to novel treatments and preventive strategies for these chronic diseases. In line with previous 
Table 6 Most cited articles

\begin{tabular}{|c|c|c|c|c|}
\hline Rank & Articles & Article type & $\begin{array}{l}\text { Total } \\
\text { citations }\end{array}$ & $\begin{array}{l}\text { Citations } \\
\text { per year }\end{array}$ \\
\hline 1. & $\begin{array}{l}\text { Bland JM, Altman DG. Statistical methods for assessing agreement between two methods of clinical } \\
\text { measurement. Lancet. 1986;1(8476):307-10. PubMed PMID: } 2868172 \text {. }\end{array}$ & Methods & 30,217 & 974.7 \\
\hline 2. & $\begin{array}{l}\text { Diabetes Control and Complications Trial Research Group, Nathan DM, Genuth S, Lachin J, Cleary P, } \\
\text { Crofford O, Davis M, Rand L, Siebert C. The effect of intensive treatment of diabetes on the } \\
\text { development and progression of long-term complications in insulin-dependent diabetes mellitus. N } \\
\text { Engl J Med. 1993;329(14):977-86. PubMed PMID: 8366922. }\end{array}$ & $\begin{array}{l}\text { Original } \\
\text { research }\end{array}$ & 11,618 & 484.1 \\
\hline 3. & UK Prospective Diabetes Study (UKPDS) Group, Turner RC, Holman RR, Cull CA, Stratton IM, Matthews & Original & 9895 & 520.8 \\
\hline
\end{tabular}
Nugent Z, Peto R. Intensive blood-glucose control with sulphonylureas or insulin compared with conventional treatment and risk of complications in patients with type 2 diabetes (UKPDS 33). Lancet. 1998;352(9131):837-53. PubMed PMID: 9742976.

4. Rossouw JE, Anderson GL, Prentice RL, LaCroix AZ, Kooperberg C, Stefanick ML, Jackson RD, Beresford SA, Howard BV, Johnson KC, Kotchen JM, Ockene J; Writing Group for the Women's Health Initiative Investigators. Risks and benefits of estrogen plus progestin in healthy postmenopausal women: principal results from the Women's Health Initiative randomized controlled trial. JAMA. 2002;288(3):32133. PubMed PMID: 12117397.

5. Knowler WC, Barrett-Connor E, Fowler SE, Hamman RF, Lachin JM, Walker EA, Nathan DM; Diabetes Prevention Program Research Group. Reduction in the incidence of type 2 diabetes with lifestyle intervention or metformin. N Engl J Med. 2002;346(6):393-403. PubMed PMID: 11832527.

6. Stupp R, Mason WP, van den Bent MJ, Weller M, Fisher B, Taphoorn MJ, Belanger K, Brandes AA, Marosi C, Bogdahn U, Curschmann J, Janzer RC, Ludwin SK, Gorlia T, Allgeier A, Lacombe D, Cairncross JG, Eisenhauer E, Mirimanoff RO; European Organisation for Research and Treatment of Cancer Brain Tumor and Radiotherapy Groups; National Cancer Institute of Canada Clinical Trials Group. Radiotherapy plus concomitant and adjuvant temozolomide for glioblastoma. N Engl J Med. 2005; 352(10):987-96. PubMed PMID: 15758009.

7. Pedersen TR, Kjekshus J, Berg K, Haghfelt T, Faergeman O, Thorgeirsson G, Pyorala K, Miettinen T, Wilhelmsen L, Olsson AG, Wedel H, Kristianson K, Thomsen H, Nordero E, Thosen B, Lyngborg K. Randomised trial of cholesterol lowering in 4444 patients with coronary heart disease: the Scandinavian Simvastatin Survival Study (4S). Lancet. 1994;344(8934):1383-9. PubMed PMID: 7968073.

8. Hurwitz H, Fehrenbacher L, Novotny W, Cartwright T, Hainsworth J, Heim W, Berlin J, Baron A, Griffing S, Holmgren E, Ferrara N, Fyfe G, Rogers B, Ross R, Kabbinavar F. Bevacizumab plus irinotecan, fluorouracil, and leucovorin for metastatic colorectal cancer. N Engl J Med. 2004;350(23):2335-42. PubMed PMID: 15175435.

9. Slamon DJ, Leyland-Jones B, Shak S, Fuchs H, Paton V, Bajamonde A, Fleming T, Eiermann W, Wolter J, Pegram M, Baselga J, Norton L. Use of chemotherapy plus a monoclonal antibody against HER2 for metastatic breast cancer that overexpresses HER2. N Engl J Med. 2001;344(11):783-92. PubMed PMID: 11248153.

10. Shepherd J, Cobbe SM, Ford I, Isles CG, Lorimer AR, MacFarlane PW, McKillop JH, Packard CJ; West of Scotland Coronary Prevention Study Group. Prevention of coronary heart disease with pravastatin in men with hypercholesterolemia. N Engl J Med. 1995;333(20):1301-7. PubMed PMID: 7566020.

11. Hodi FS, O'Day SJ, McDermott DF, Weber RW, Sosman JA, Haanen JB, Gonzalez R, Robert C, Schadendorf D, Hassel JC, Akerley W, van den Eertwegh AJ, Lutzky J, Lorigan P, Vaubel JM, Linette GP, Hogg D, Ottensmeier CH, Lebbé C, Peschel C, Quirt I, Clark Jl, Wolchok JD, Weber JS, Tian J, Yellin MJ, Nichol GM, Hoos A, Urba WJ. Improved survival with ipilimumab in patients with metastatic melanoma. N Engl J Med. 2010;363(8):711-23. PubMed PMID: 20525992.

12. Heart Outcomes Prevention Evaluation Study Investigators, Yusuf S, Sleight P, Pogue J, Bosch J, Davies $\mathrm{R}$, Dagenais G. Effects of an angiotensin-converting-enzyme inhibitor, ramipril, on cardiovascular events in high-risk patients. N Engl J Med. 2000;342(3):145-53. PubMed PMID: 10639539.

13. National Institute of Neurological Disorders and Stroke rt-PA Stroke Study Group, Marler JR, Brott T, Bro- Original derick J, kothari R, Odonoghue M, Barsan W, Tomsick T, Spilker J, Miller R, Sauerbeck L, Jarrell J, Kelly J, research Perkins T, McDonald T, Rorick M, Hickey C, Armitage J. Tissue plasminogen activator for acute ischemic stroke. N Engl J Med. 1995;333(24):1581-7. PubMed PMID: 7477192.

14. Tuomilehto J, Lindström J, Eriksson JG, Valle TT, Hämäläinen H, llanne-Parikka P, Keinänen-Kiukaanniemi Original S, Laakso M, Louheranta A, Rastas M, Salminen V, Uusitupa M; Finnish Diabetes Prevention Study Group. research Prevention of type 2 diabetes mellitus by changes in lifestyle among subjects with impaired glucose tolerance. N Engl J Med. 2001;344(18):1343-50. PubMed PMID: 11333990.

15. Rivers E, Nguyen B, Havstad S, Ressler J, Muzzin A, Knoblich B, Peterson E, Tomlanovich M; Early GoalDirected Therapy Collaborative Group. Early goal-directed therapy in the treatment of severe sepsis and septic shock. N Engl J Med. 2001;345(19):1368-77. PubMed PMID: 11794169.

16. van den Berghe $G$, Wouters $P$, Weekers F, Verwaest $C$, Bruyninckx F, Schetz M, Vlasselaers D, Ferdinande P, Lauwers P, Bouillon R. Intensive insulin therapy in critically ill patients. N Engl J Med. 2001;345(19):1359-67. 
Table 6 Most cited articles (Continued)

\begin{tabular}{lll}
\hline Rank Articles & Article type Total Citations
\end{tabular}

PubMed PMID: 11,794,168.

17. Llovet JM, Ricci S, Mazzaferro V, Hilgard P, Gane E, Blanc JF, de Oliveira AC, Santoro A, Raoul JL, Forner A, Schwartz M, Porta C, Zeuzem S, Bolondi L, Greten TF, Galle PR, Seitz JF, Borbath I, Häussinger D, Giannaris T, Shan M, Moscovici M, Voliotis D, Bruix J; SHARP Investigators Study Group. Sorafenib in advanced hepatocellular carcinoma. N Engl J Med. 2008;359(4):378-90. PubMed PMID: 18650514.

18. Sacks FM, Pfeffer MA, Moye LA, Rouleau JL, Rutherford JD, Cole TG, Brown L, Warnica JW, Arnold JM, Original Wun CC, Davis BR, Braunwald E. The effect of pravastatin on coronary events after myocardial infarction research in patients with average cholesterol levels. Cholesterol and Recurrent Events Trial investigators. N Engl J Med. 1996;335(14):1001-9. PubMed PMID: 8801446.

19. Collins R, Armitage J, Parish S, Sleight P, Peto R; Heart Protection Study Collaborative Group. MRC/BHF Original Heart Protection Study of cholesterol lowering with simvastatin in 20.536 high-risk individuals: a rando- research mised placebo-controlled trial. Lancet. 2002;360(9326):7-22. PubMed PMID: 12114036.

20. Connolly SJ, Ezekowitz MD, Yusuf S, Eikelboom J, Oldgren J, Parekh A, Pogue J, Reilly PA, Themeles E, Varrone J, Wang S, Alings M, Xavier D, Zhu J, Diaz R, Lewis BS, Darius H, Diener HC, Joyner CD, Wallentin L; RE-LY Steering Committee and Investigators. Dabigatran versus warfarin in patients with atrial fibrillation. N Engl J Med. 2009;361(12):1139-51. PubMed PMID: 19717844.

21. Pitt B, Zannad F, Remme WJ, Cody R, Castaigne A, Perez A, Palensky J, Wittes J. The effect of spironolactone on morbidity and mortality in patients with severe heart failure. Randomized Aldactone Evaluation Study Investigators. N Engl J Med. 1999;341(10):709-17. PubMed PMID: 10471456.

22. Manns MP, McHutchison JG, Gordon SC, Rustgi VK, Shiffman M, Reindollar R, Goodman ZD, Koury K, Ling M, Albrecht JK. Peginterferon alfa-2b plus ribavirin compared with interferon alfa-2b plus ribavirin for initial treatment of chronic hepatitis C: a randomised trial. Lancet. 2001;358(9286):958-65. PubMed PMID: 11583749.

23. Fried MW, Shiffman ML, Reddy KR, Smith C, Marinos G, Gonçales FL Jr., Häussinger D, Diago M, Carosi G, Dhumeaux D, Craxi A, Lin A, Hoffman J, Yu J. Peginterferon alfa-2a plus ribavirin for chronic hepatitis C virus infection. N Engl J Med. 2002;347(13):975-82. PubMed PMID: 12324553.

24. Acute Respiratory Distress Syndrome Network, Brower RG, Matthay MA, Morris A, Schoenfeld D, Thompson BT, Wheeler A. Ventilation with lower tidal volumes as compared with traditional tidal volumes for acute lung injury and the acute respiratory distress syndrome. N Engl J Med. 2000;342(18): 1301-8. PubMed PMID: 10793162.

25. Topalian SL, Hodi FS, Brahmer JR, Gettinger SN, Smith DC, McDermott DF, Powderly JD, Carvajal RD, Sosman JA, Atkins MB, Leming PD, Spigel DR, Antonia SJ, Horn L, Drake CG, Pardoll DM, Chen L, Sharfman WH, Anders RA, Taube JM, McMiller TL, Xu H, Korman AJ, Jure-Kunkel M, Agrawal S, McDonald D, Kollia GD, Gupta A, Wigginton JM, Sznol M. Safety, activity, and immune correlates of anti-PD-1 antibody in cancer. N Engl J Med. 2012;366(26):2443-54. PubMed PMID: 22658127.

26. Pfeffer MA, Braunwald E, Moyé LA, Basta L, Brown EJ Jr., Cuddy TE, Davis BR, Geltman EM, Goldman S, Flaker GC, Klein M, Lamas GA, Packer M, Rouleau J, Rouleau JL, Rutherford J, Wertheimer JH; The SAVE Investigators. Effect of captopril on mortality and morbidity in patients with left ventricular dysfunction after myocardial infarction. Results of the survival and ventricular enlargement trial. N Engl J Med. 1992; 327(10):669-77. PubMed PMID: 1386652.

27. Hulley S, Grady D, Bush T, Furberg C, Herrington D, Riggs B, Vittinghoff E. Randomized trial of estrogen plus progestin for secondary prevention of coronary heart disease in postmenopausal women. Heart and Estrogen/progestin Replacement Study (HERS) Research Group. JAMA. 1998;280(7):605-13. PubMed PMID: 9718051.

28. North American Symptomatic Carotid Endarterectomy Trial Collaborators, Barnett HJM, Taylor DW, Haynes RB, Sackett DL, Peerless SJ, Ferguson GG, Fox AJ, Rankin RN, Hachinski VC Wiebers DO, Eliasziw M. Beneficial effect of carotid endarterectomy in symptomatic patients with high-grade carotid stenosis. N Engl J Med. 1991;325(7):445-53. PubMed PMID: 1852179. 29. Mok TS, Wu YL, Thongprasert S, Yang CH, Chu DT, Saijo N, Sunpaweravong P, Han B, Margono B,
Ichinose Y, Nishiwaki Y, Ohe Y, Yang JJ, Chewaskulyong B, Jiang H, Duffield EL, Watkins CL, Armour AA, research Fukuoka M. Gefitinib or carboplatin-paclitaxel in pulmonary adenocarcinoma. N Engl J Med. 2009; 361(10):947-57. PubMed PMID: 19692680.

30. Yusuf S, Zhao F, Mehta SR, Chrolavicius S, Tognoni G, Fox KK; Clopidogrel in Unstable Angina to Prevent Original Recurrent Events Trial Investigators. Effects of clopidogrel in addition to aspirin in patients with acute coronary research syndromes without ST-segment elevation. N Engl J Med. 2001;345(7):494-502. PubMed PMID: 11519503.

31. Brenner BM, Cooper ME, de Zeeuw D, Keane WF, Mitch WE, Parving HH, Remuzzi G, Snapinn SM, Zhang Z, Shahinfar S; RENAAL Study Investigators. Effects of losartan on renal and cardiovascular outcomes in patients with type 2 diabetes and nephropathy. N Engl J Med. 2001;345(12):861-9. PubMed PMID: 11565518. 
Table 6 Most cited articles (Continued)

\begin{tabular}{|c|c|c|c|c|}
\hline Rank & Articles & Article type & $\begin{array}{l}\text { Total } \\
\text { citations }\end{array}$ & $\begin{array}{l}\text { Citations } \\
\text { per year }\end{array}$ \\
\hline 32. & $\begin{array}{l}\text { Lewis EJ, Hunsicker LG, Bain RP, Rohde RD. The effect of angiotensin-converting-enzyme inhibition on diabetic } \\
\text { nephropathy. The Collaborative Study Group. N Engl J Med. 1993;329(20):1456-62. PubMed PMID: } 8413456 .\end{array}$ & $\begin{array}{l}\text { Original } \\
\text { research }\end{array}$ & 3965 & 165.2 \\
\hline 33 & Chapman PB, Hauschild A, Robert C, Haanen JB, Ascierto P, Larkin J, Dummer R, Garbe C, Testori A, & Original & 3952 & 658.7 \\
\hline
\end{tabular}

Maio M, Hogg D, Lorigan P, Lebbe C, Jouary T, Schadendorf D, Ribas A, O'Day SJ, Sosman JA, Kirkwood research JM, Eggermont AM, Dreno B, Nolop K, Li J, Nelson B, Hou J, Lee RJ, Flaherty KT, McArthur GA; BRIM-3 Study Group. Improved survival with vemurafenib in melanoma with BRAF V600E mutation. N Engl J Med. 2011;364(26):2507-16. PubMed PMID: 21639808

34. Shepherd FA, Rodrigues Pereira J, Ciuleanu T, Tan EH, Hirsh V, Thongprasert S, Campos D, Maoleekoonpiroj Original S, Smylie M, Martins R, van Kooten M, Dediu M, Findlay B, Tu D, Johnston D, Bezjak A, Clark G, Santabárbara research $\mathrm{P}$, Seymour L; National Cancer Institute of Canada Clinical Trials Group. Erlotinib in previously treated nonsmall-cell lung cancer. N Engl J Med. 2005;353(2):123-32. PubMed PMID: 16014882.

35. CAPRIE Steering Committee, Gent M, Beaumont D, Blanchard J, Bousser MG, Coffman J, Easton JD, Hampton JR, Harker LA, Janzon L, Kusmierek JJ, Panak E, Roberts RS, Shannon JS, Sicurella J, Tognoni G, Topol EJ, Verstraet M, Warlow C, Cairns JA, Chesebro JH, von der Lippe G, Ross Russell RW, Wolf PA, Boissel JP, Friedman L, Fuster V, Harrison MG, Pocock S, et al. A randomised, blinded, trial of clopidogrel versus aspirin in patients at risk of ischaemic events (CAPRIE). Lancet. 1996;348(9038):1329-39. PubMed PMID: 8918275.

36. Ridker PM, Cushman M, Stampfer MJ, Tracy RP, Hennekens CH. Inflammation, aspirin, and the risk of cardiovascular disease in apparently healthy men. N Engl J Med. 1997;336(14):973-9. PubMed PMID: 9077376.

37. UK Prospective Diabetes Study (UKPDS) Group, Turner RC, Holman RR, Stratton IM, Cull CA, Matthews DR, Frighi V, Wright D, Neil A, Kohner E, McElroy K, Fox C, Hadden D, et al. Effect of intensive bloodglucose control with metformin on complications in overweight patients with type 2 diabetes (UKPDS 34). Lancet. 1998;352(9131):854-65. PubMed PMID: 9742977.

38. Moss AJ, Zareba W, Hall WJ, Klein H, Wilber DJ, Cannom DS, Daubert JP, Higgins SL, Brown MW, Andrews ML; Multicenter Automatic Defibrillator Implantation Trial II Investigators. Prophylactic implantation of a defibrillator in patients with myocardial infarction and reduced ejection fraction. N Engl J Med. 2002;346(12):877-83. PubMed PMID: 11907286.

39. Action to Control Cardiovascular Risk in Diabetes Study Group, Gerstein HC, Miller ME, Byington RP, Goff DC Jr., Bigger JT, Buse JB, Cushman WC, Genuth S, Ismail-Beigi F, Grimm RH Jr., Probstfield JL, Simons-Morton DG, Friedewald WT. Effects of intensive glucose lowering in type 2 diabetes. N Engl J Med. 2008;358(24):2545-59. PubMed PMID: 18539917.

40. Hansson L, Zanchetti A, Carruthers SG, Dahlöf B, Elmfeldt D, Julius S, Ménard J, Rahn KH, Wedel H, Westerling $S$. Effects of intensive blood-pressure lowering and low-dose aspirin in patients with hypertension: principal results of the Hypertension Optimal Treatment (HOT) randomised trial. HOT Study Group. Lancet. 1998;351(9118):1755-62. PubMed PMID: 9635947.

41. Sandler A, Gray R, Perry MC, Brahmer J, Schiller JH, Dowlati A, Lilenbaum R, Johnson DH. Paclitaxel carboplatin alone or with bevacizumab for non-small-cell lung cancer. N Engl J Med. 2006;355(24): 2542-50. PubMed PMID: 17167137.

42. Fisher B, Costantino JP, Wickerham DL, Redmond CK, Kavanah M, Cronin WM, Vogel V, Robidoux A, Dimitrov N, Atkins J, Daly M, Wieand S, Tan-Chiu E, Ford L, Wolmark N. Tamoxifen for prevention of breast cancer: report of the National Surgical Adjuvant Breast and Bowel Project P-1 Study. J Natl Cancer Inst. 1998;90(18):1371-88. PubMed PMID: 9747868.

43. Bernard GR, Vincent JL, Laterre PF, LaRosa SP, Dhainaut JF, Lopez-Rodriguez A, Steingrub JS, Garber GE, Helterbrand JD, Ely EW, Fisher CJ Jr.; Recombinant human protein C Worldwide Evaluation in Severe Sepsis (PROWESS) study group. Efficacy and safety of recombinant human activated protein C for severe sepsis. N Engl J Med. 2001;344(10):699-709. PubMed PMID: 11236773.

44. Downs JR, Clearfield M, Weis S, Whitney E, Shapiro DR, Beere PA, Langendorfer A, Stein EA, Kruyer W, Gotto AM Jr. Primary prevention of acute coronary events with lovastatin in men and women with average cholesterol levels: results of AFCAPS/TexCAPS. Air Force/Texas Coronary Atherosclerosis Prevention Study. JAMA. 1998:279(20):1615-22. PubMed PMID: 9613910

45. Long-Term Intervention with Pravastatin in Ischaemic Disease (LIPID) Study Group. Prevention of cardiovascular events and death with pravastatin in patients with coronary heart disease and a broad range of initial cholesterol levels. N Engl J Med. 1998;339(19):1349-57. PubMed PMID: 9841303.

46. Le Gall JR, Lemeshow S, Saulnier F. A new Simplified Acute Physiology Score (SAPS II) based on a European/North American multicenter study. JAMA. 1993;270(24):2957-63. PubMed PMID: 8254858

47. Motzer RJ, Hutson TE, Tomczak P, Michaelson MD, Bukowski RM, Rixe O, Oudard S, Negrier S, Szczylik C, Original Kim ST, Chen I, Bycott PW, Baum CM, Figlin RA. Sunitinib versus interferon alfa in metastatic renal-cell carcinoma. N Engl J Med. 2007;356(2):115-24. PubMed PMID: 17215529.

Original

research

Original

research

Original research

Original research 
Table 6 Most cited articles (Continued)

Rank Articles

Article type

8. Burris HA 3rd, Moore MJ, Andersen J, Green MR, Rothenberg ML, Modiano MR, Cripps MC, Portenoy RK, Original Storniolo AM, Tarassoff P, Nelson R, Dorr FA, Stephens CD, Von Hoff DD. Improvements in survival and research clinical benefit with gemcitabine as first-line therapy for patients with advanced pancreas cancer: a randomized trial. J Clin Oncol. 1997;15(6):2403-13. PubMed PMID: 9196156.

49 Patel MR, Mahaffey KW, Garg J, Pan G, Singer DE, Hacke W, Breithardt G, Halperin JL, Hankey GJ, Piccini JP, Becker RC, Nessel CC, Paolini JF, Berkowitz SD, Fox KA, Califf RM; ROCKET AF Investigators. Rivaroxaban versus warfarin in nonvalvular atrial fibrillation. N Engl J Med. 2011;365(10):883-91. PubMed PMID: 21830957.

50. Ridker PM, Danielson E, Fonseca FA, Genest J, Gotto AM Jr., Kastelein JJ, Koenig W, Libby P, Lorenzatti AJ, MacFadyen JG, Nordestgaard BG, Shepherd J, Willerson JT, Glynn RJ; JUPITER Study Group. Rosuvastatin to prevent vascular events in men and women with elevated C-reactive protein. N Engl J Med. 2008;359(21):2195-207. PubMed PMID: 18997196

51. Serruys PW, de Jaegere P, Kiemeneij F, Macaya C, Rutsch W, Heyndrickx G, Emanuelsson H, Marco J, Legrand $V$, Materne $P$, et al. A comparison of balloon-expandable-stent implantation with balloon angioplasty in patients with coronary artery disease. Benestent Study Group. N Engl J Med. 1994;331(8): 489-95. PubMed PMID: 8041413.

52. Cleland JG, Daubert JC, Erdmann E, Freemantle N, Gras D, Kappenberger L, Tavazzi L; Cardiac Resynchronization-Heart Failure (CARE-HF) Study Investigators. The effect of cardiac resynchronization on morbidity and mortality in heart failure. N Engl J Med. 2005;352(15):1539-49. PubMed PMID: 15753115.

53. Bardy GH, Lee KL, Mark DB, Poole JE, Packer DL, Boineau R, Domanski M, Troutman C, Anderson J, Johnson G, McNulty SE, Clapp-Channing N, Davidson-Ray LD, Fraulo ES, Fishbein DP, Luceri RM, Ip JH; Sudden Cardiac Death in Heart Failure Trial (SCD-HeFT) Investigators. Amiodarone or an implantable cardioverterdefibrillator for congestive heart failure. N Engl J Med. 2005;352(3):225-37. PubMed PMID: 15659722.

54. Wiviott SD, Braunwald E, McCabe CH, Montalescot G, Ruzyllo W, Gottlieb S, Neumann FJ, Ardissino D, De Servi S, Murphy SA, Riesmeyer J, Weerakkody G, Gibson CM, Antman EM; TRITON-TIMI 38 Investigators. Prasugrel versus clopidogrel in patients with acute coronary syndromes. N Engl J Med. 2007; 357(20):2001-15. PubMed PMID: 17982182.

55. Lewis EJ, Hunsicker LG, Clarke WR, Berl T, Pohl MA, Lewis JB, Ritz E, Atkins RC, Rohde R, Raz I; Collaborative Study Group. Renoprotective effect of the angiotensin-receptor antagonist irbesartan in patients with nephropathy due to type 2 diabetes. N Engl J Med. 2001;345(12):851-60. PubMed PMID: 11565517.

56. SOLVD Investigators, Yusuf S, Pitt B, Davis CE, Hood WB, Cohn JN. Effect of enalapril on survival in patients with reduced left ventricular ejection fractions and congestive heart failure. N Engl J Med. 1991;325(5):293-302. PubMed PMID: 2057034.

57. Lieberman JA, Stroup TS, McEvoy JP, Swartz MS, Rosenheck RA, Perkins DO, Keefe RS, Davis SM, Davis CE, Lebowitz BD, Severe J, Hsiao JK; Clinical Antipsychotic Trials of Intervention Effectiveness (CATIE) Investigators. Effectiveness of antipsychotic drugs in patients with chronic schizophrenia. N Engl J Med. 2005;353(12):1209-23. PubMed PMID: 16172203.

58. Cunningham D, Humblet Y, Siena S, Khayat D, Bleiberg H, Santoro A, Bets D, Mueser M, Harstrick A Verslype C, Chau I, Van Cutsem E. Cetuximab monotherapy and cetuximab plus irinotecan in irinotecanrefractory metastatic colorectal cancer. N Engl J Med. 2004;351(4):337-45. PubMed PMID: 15269313.

59. Dahlöf B, Devereux RB, Kjeldsen SE, Julius S, Beevers G, de Faire U, Fyhrquist F, Ibsen H, Kristiansson K, Lederballe-Pedersen O, Lindholm LH, Nieminen MS, Omvik P, Oparil S, Wedel H; LIFE Study Group. Cardiovascular morbidity and mortality in the Losartan Intervention For Endpoint reduction in hypertension study (LIFE): a randomised trial against atenolol. Lancet. 2002;359(9311):995-1003. PubMed PMID: 11937178.

60. Schiller JH, Harrington D, Belani CP, Langer C, Sandler A, Krook J, Zhu J, Johnson DH; Eastern Cooperative Oncology Group. Comparison of four chemotherapy regimens for advanced non-small-cell research lung cancer. N Engl J Med. 2002;346(2):92-8. PubMed PMID: 11784875.

61. Cohen MS, Chen YQ, McCauley M, Gamble T, Hosseinipour MC, Kumarasamy N, Hakim JG, Kumwenda J, Grinsztejn B, Pilotto JH, Godbole SV, Mehendale S, Chariyalertsak S, Santos BR, Mayer KH, Hoffman IF, Eshleman SH, Piwowar-Manning E, Wang L, Makhema J, Mills LA, de Bruyn G, Sanne I, Eron J, Gallant J, Havlir D, Swindells S, Ribaudo H, Elharrar V, Burns D, Taha TE, Nielsen-Saines K, Celentano D, Essex M, Fleming TR; HPTN 052 Study Team. Prevention of HIV-1 infection with early antiretroviral therapy. N Engl J Med. 2011;365(6):493-505. PubMed PMID: 21767103.

62. Stearne MR, Palmer SL, Hammersley MS, Franklin SL, Spivey RS, Levy JC, Tidy CR, Bell NJ, Steemson J, Barrow BA, Coster R, Waring K, Nolan J, Truscott E, Walravens N, Cook L, Lampard H, Merle C, Parker P, McVittie J, et al. UK Prospective Diabetes Study Group. Tight blood pressure control and risk of macrovascular and microvascular complications in type 2 diabetes: UKPDS 38. BMJ. 1998;317(7160): 703-13. PubMed PMID: 9732337. 
Table 6 Most cited articles (Continued)

\begin{tabular}{|c|c|c|c|c|}
\hline Rank & Articles & Article type & $\begin{array}{l}\text { Total } \\
\text { citations }\end{array}$ & $\begin{array}{l}\text { Citations } \\
\text { per year }\end{array}$ \\
\hline 63. & $\begin{array}{l}\text { Holman RR, Paul SK, Bethel MA, Matthews DR. Neil HA. 10-year follow-up of intensive glucose control } \\
\text { in type } 2 \text { diabetes. N Engl J Med. 2008;359(15):1577-89. PubMed PMID: } 18784090 .\end{array}$ & $\begin{array}{l}\text { Secondary } \\
\text { analysis }\end{array}$ & 3349 & 372.1 \\
\hline 64. & $\begin{array}{l}\text { Escudier B, Eisen T, Stadler WM, Szczylik C, Oudard S, Siebels M, Negrier S, Chevreau C, Solska E, Desai } \\
\text { AA, Rolland F, Demkow T, Hutson TE, Gore M, Freeman S, Schwartz B, Shan M, Simantov R, Bukowski } \\
\text { RM; TARGET Study Group. Sorafenib in advanced clear-cell renal-cell carcinoma. N Engl J Med. 2007; } \\
\text { 356(2):125-34. PubMed PMID: } 17215530 .\end{array}$ & $\begin{array}{l}\text { Original } \\
\text { research }\end{array}$ & 3313 & 331.3 \\
\hline 65. & $\begin{array}{l}\text { Tannock IF, de Wit R, Berry WR, Horti J, Pluzanska A, Chi KN, Oudard S, Théodore C, James ND, } \\
\text { Turesson I, Rosenthal MA, Eisenberger MA; TAX } 327 \text { Investigators. Docetaxel plus prednisone or } \\
\text { mitoxantrone plus prednisone for advanced prostate cancer. N Engl J Med. 2004;351(15):1502-12. } \\
\text { PubMed PMID: } 15470213 .\end{array}$ & $\begin{array}{l}\text { Original } \\
\text { research }\end{array}$ & 3286 & 252.8 \\
\hline 66. & $\begin{array}{l}\text { Romond EH, Perez EA, Bryant J, Suman VJ, Geyer CE Jr., Davidson NE, Tan-Chiu E, Martino S, Paik S, } \\
\text { Kaufman PA, Swain SM, Pisansky TM, Fehrenbacher L, Kutteh LA, Vogel VG, Visscher DW, Yothers G, Jen- } \\
\text { kins RB, Brown AM, Dakhil SR, Mamounas EP, Lingle WL, Klein PM, Ingle JN, Wolmark N. Trastuzumab } \\
\text { plus adjuvant chemotherapy for operable HER2-positive breast cancer. N Engl J Med. 2005;353(16): } \\
\text { 1673-84. PubMed PMID: } 16236738 .\end{array}$ & $\begin{array}{l}\text { Original } \\
\text { research }\end{array}$ & 3282 & 273.5 \\
\hline 67. & $\begin{array}{l}\text { Fischman DL, Leon MB, Baim DS, Schatz RA, Savage MP, Penn I, Detre K, Veltri L, Ricci D, Nobuyoshi M, } \\
\text { Cleman M, Heuser R, Almond D, Teirstein PS, Fish RD, Colombo A, Brinker J, Moses J. A randomized } \\
\text { comparison of coronary-stent placement and balloon angioplasty in the treatment of coronary artery dis- } \\
\text { ease. Stent Restenosis Study Investigators. N Engl J Med. 1994;331(8):496-501. PubMed PMID: 8041414. }\end{array}$ & $\begin{array}{l}\text { Original } \\
\text { research }\end{array}$ & 3263 & 141.9 \\
\hline 68. & $\begin{array}{l}\text { Paik S, Shak S, Tang G, Kim C, Baker J, Cronin M, Baehner FL, Walker MG, Watson D, Park T, Hiller W, } \\
\text { Fisher ER, Wickerham DL, Bryant J, Wolmark N. A multigene assay to predict recurrence of tamoxifen- } \\
\text { treated, node negative breast cancer. N Engl J Med. 2004;351(27):2817-26. PubMed PMID: } 15591335 .\end{array}$ & $\begin{array}{l}\text { Original } \\
\text { research }\end{array}$ & 3249 & 249.9 \\
\hline 69. & $\begin{array}{l}\text { Bristow MR, Saxon LA, Boehmer J, Krueger S, Kass DA, De Marco T, Carson P, DiCarlo L, DeMets D, White } \\
\text { BG, DeVries DW. Feldman AM; Comparison of Medical Therapy, Pacing, and Defibrillation in Heart Failure } \\
\text { (COMPANION) Investigators. Cardiac-resynchronization therapy with or without an implantable defibrillator } \\
\text { in advanced chronic heart failure. N Engl J Med. 2004;350(21):2140-50. PubMed PMID: } 15152059 \text {. }\end{array}$ & $\begin{array}{l}\text { Original } \\
\text { research }\end{array}$ & 3248 & 249.8 \\
\hline 70. & ADVANCE Collaborative Group, Patel A, MacMahon S, Chalmers J, Neal B, Billot L, Woodward M, Marre & Original & 3215 & 357.2 \\
\hline
\end{tabular}

M, Cooper M, Glasziou P, Grobbee D, Hamet P, Harrap S, Heller S, Liu L, Mancia G, Mogensen CE, Pan C, research Poulter N, Rodgers A, Williams B, Bompoint S, de Galan BE, Joshi R, Travert F. Intensive blood glucose control and vascular outcomes in patients with type 2 diabetes. N Engl J Med. 2008;358(24):2560-72. PubMed PMID: 18539916.

71. Granger CB, Alexander JH, McMurray JJ, Lopes RD, Hylek EM, Hanna M, Al-Khalidi HR, Ansell J, Atar D, Avezum A, Bahit MC, Diaz R, Easton JD, Ezekowitz JA, Flaker G, Garcia D, Geraldes M, Gersh BJ, Golitsyn S, Goto S, Hermosillo AG, Hohnloser SH, Horowitz J, Mohan P, Jansky P, Lewis BS, Lopez-Sendon JL, Pais P, Parkhomenko A, Verheugt FW, Zhu J, Wallentin L; ARISTOTLE Committees and Investigators. Apixaban versus warfarin in patients with atrial fibrillation. N Engl J Med. 2011;365(11):981-92. PubMed PMID: 21870978.

72. Frick MH, Elo O, Haapa K, Heinonen OP, Heinsalmi P, Helo P, Huttunen JK, Kaitaniemi P, Koskinen P, Manninen V, Maenpaa H, Malkonen M, Manttari M, Norola S, Pasternack A, Pikkarainen J, Romo M, Sjöblom T, Nikiilä EA. Helsinki Heart Study: primary-prevention trial with gemfibrozil in middle-aged men with dyslipidemia. Safety of treatment, changes in risk factors, and incidence of coronary heart disease. N Engl J Med. 1987;317(20):1237-45. PubMed PMID: 3313041.

73. Kane J, Honigfeld G, Singer J, Meltzer H. Clozapine for the treatment-resistant schizophrenic. A doubleblind comparison with chlorpromazine. Arch Gen Psychiatry. 1988;45(9):789-96. PubMed PMID: 3046553.

74. Leon MB, Smith CR, Mack M, Miller DC, Moses JW, Svensson LG, Tuzcu EM, Webb JG, Fontana GP, Makkar RR, Brown DL, Block PC, Guyton RA, Pichard AD, Bavaria JE, Herrmann HC, Douglas PS, Petersen $J \mathrm{~L}$, Akin JJ, Anderson WN, Wang D, Pocock S; PARTNER Trial Investigators. Transcatheter aortic-valve implantation for aortic stenosis in patients who cannot undergo surgery. N Engl J Med. 2010;363(17): 1597-607. PubMed PMID: 20961243.

75. Coiffier B, Lepage E, Briere J, Herbrecht R, Tilly H, Bouabdallah R, Morel P, Van Den Neste E, Salles G, Gaulard P, Reyes F, Lederlin P, Gisselbrecht C. CHOP chemotherapy plus rituximab compared with CHOP alone in elderly patients with diffuse large-B-cell lymphoma. N Engl J Med. 2002;346(4):235-42. PubMed PMID: 11807147.

76. Packer M, Bristow MR, Cohn JN, Colucci WS, Fowler MB, Gilbert EM, Shusterman NH. The effect of carvedilol on morbidity and mortality in patients with chronic heart failure. U.S. Carvedilol Heart Failure Study Group. N Engl J Med. 1996;334(21):1349-55. PubMed PMID: 8614419.

77. Sauer R, Becker H, Hohenberger W, Rödel C, Wittekind C, Fietkau R, Martus P, Tschmelitsch J, Hager E, Hess CF, Karstens JH, Liersch T, Schmidberger H, Raab R; German Rectal Cancer Study Group. Preoperative versus postoperative chemoradiotherapy for rectal cancer. N Engl J Med. 2004;351(17) 1731-40. PubMed PMID: 15496622. 
Table 6 Most cited articles (Continued)

Rank Articles

Article type

78. $\quad$ Rosenfeld PJ, Brown DM, Heier JS, Boyer DS, Kaiser PK, Chung CY, Kim RY; MARINA Study Group. Ranibizumab for neovascular age-related macular degeneration. N Engl J Med. 2006;355(14):1419-31. PubMed PMID: 17021318.

79. Piccart-Gebhart MJ, Procter M, Leyland-Jones B, Goldhirsch A, Untch M, Smith I, Gianni L, Baselga J, Bell Original R, Jackisch C, Cameron D, Dowsett M, Barrios CH, Steger G, Huang CS, Andersson M, Inbar M, Lichinitser research M, Láng I, Nitz U, Iwata H, Thomssen C, Lohrisch C, Suter TM, Rüschoff J, Suto T, Greatorex V, Ward C, Straehle C, McFadden E, Dolci MS, Gelber RD; Herceptin Adjuvant (HERA) Trial Study Team. Trastuzumab after adjuvant chemotherapy in HER2-positive breast cancer. N Engl J Med. 2005;353(16):1659-72. PubMed PMID: 16236737.

80. Moses JW, Leon MB, Popma JJ, Fitzgerald PJ, Holmes DR, O'Shaughnessy C, Caputo RP, Kereiakes DJ, Original Williams DO, Teirstein PS, Jaeger JL, Kuntz RE; SIRIUS Investigators. Sirolimus-eluting stents versus stand- research ard stents in patients with stenosis in a native coronary artery. N Engl J Med. 2003;349(14):1315-23. PubMed PMID: 14523139.

81. Bernard SA, Gray TW, Buist MD, Jones BM, Silvester W, Gutteridge G, Smith K. Treatment of comatose survivors of out-of-hospital cardiac arrest with induced hypothermia. N Engl J Med. 2002 Feb 21;346(8): 557-63. PubMed PMID: 11856794

82. Abraham WT, Fisher WG, Smith AL, Delurgio DB, Leon AR, Loh E, Kocovic DZ, Packer M, Clavell AL, Hayes DL, Ellestad M, Trupp RJ, Underwood J, Pickering F, Truex C, McAtee P, Messenger J; MIRACLE Study Group. Multicenter InSync Randomized Clinical Evaluation, Cardiac resynchronization in chronic heart failure. N Engl J Med. 2002;346(24):1845-53. PubMed PMID: 12063368.

83. Wallentin L, Becker RC, Budaj A, Cannon CP, Emanuelsson H, Held C, Horrow J, Husted S, James S, Katus H, Mahaffey KW, Scirica BM, Skene A, Steg PG, Storey RF, Harrington RA: PLATO Investigators, Freij research A, Thorsén M. Ticagrelor versus clopidogrel in patients with acute coronary syndromes. N Engl J Med. 2009;361(11):1045-57. PubMed PMID: 19717846.

84. Walker M, Marler JR, Goldstein M, Grady PA, Toole JF, Baker WH, Castaldo JE, Chambless LE, Moore WS, Robertson JT, Young B, Howard VJ, Purvis S, Vernon DD, Needham K, Beck P, Celani VJ, Sauerbeck L, von Rajcs JA. Atkins D. Endarterectomy for asymptomatic carotid artery stenosis. Executive Committee for the Asymptomatic Carotid Atherosclerosis Study. JAMA. 1995;273(18):1421-8. PubMed PMID: 7723155.

85. Cannon CP, Braunwald E, McCabe CH, Rader DJ, Rouleau JL, Belder R, Joyal SV, Hill KA, Pfeffer MA Skene AM; Pravastatin or Atorvastatin Evaluation and Infection Therapy-Thrombolysis in Myocardial Infarction 22 Investigators. Intensive versus moderate lipid lowering with statins after acute coronary syndromes. N Engl J Med. 2004;350(15):1495-504. PubMed PMID: 15007110.

86. Hacke W, Kaste M, Bluhmki E, Brozman M, Dávalos A, Guidetti D, Larrue V, Lees KR, Medeghri Z, Machnig T, Schneider D, von Kummer R, Wahlgren N, Toni D; ECASS Investigators. Thrombolysis with alteplase 3 to $4.5 \mathrm{~h}$ after acute ischemic stroke. N Engl J Med. 2008;359(13):1317-29. PubMed PMID: 18815396.

87. Anderson GL, Limacher M, Assaf AR, Bassford T, Beresford SA, Black H, Bonds D, Brunner R, Brzyski R, Caan B, Chlebowski R, Curb D, Gass M, Hays J, Heiss G, Hendrix S, Howard BV, Hsia J, Hubbell A, Jackson R, Johnson $K C$, Judd H, Kotchen JM, Kuller L, LaCroix AZ, Lane D, Langer RD, Lasser N, Lewis CE, Manson J, Margolis K, Ockene J, O'Sullivan MJ, Phillips L, Prentice RL, Ritenbaugh C, Robbins J, Rossouw JE, Sarto G, Stefanick ML, Van Horn L, Wactawski-Wende J, Wallace R, Wassertheil-Smoller S; Women's Health Initiative Steering Committee. Effects of conjugated equine estrogen in postmenopausal women with hysterectomy: the Women's Health Initiative randomized controlled trial. JAMA. 2004;291(14):1701-12. PubMed PMID: 15082697.

88. Bonner JA, Harari PM, Giralt J, Azarnia N, Shin DM, Cohen RB, Jones CU, Sur R, Raben D, Jassem J, Ove R, Kies MS, Baselga J, Youssoufian H, Amellal N, Rowinsky EK, Ang KK. Radiotherapy plus cetuximab for squamouscell carcinoma of the head and neck. N Engl J Med. 2006;354(6):567-78. PubMed PMID: 16467544

89. Stupp R, Hegi ME, Mason WP, van den Bent MJ, Taphoorn MJ, Janzer RC, Ludwin SK, Allgeier A, Fisher B, Belanger K, Hau P, Brandes AA, Gijtenbeek J, Marosi C, Vecht CJ, Mokhtari K, Wesseling P, Villa S, Eisenhauer E, Gorlia T, Weller M, Lacombe D, Cairncross JG, Mirimanoff RO; European Organisation for Research and Treatment of Cancer Brain Tumour and Radiation Oncology Groups; National Cancer Institute of Canada Clinical Trials Group. Effects of radiotherapy with concomitant and adjuvant temozolomide versus radiotherapy alone on survival in glioblastoma in a randomised phase III study: 5-year analysis of the EORTC-NCIC trial. Lancet Oncol. 2009 May;10(5):459-66. PubMed PMID: 19269895.

90. Morice MC, Serruys PW, Sousa JE, Fajadet J, Ban Hayashi E, Perin M, Colombo A, Schuler G, Barragan P, Guagliumi G, Molnàr F, Falotico R; RAVEL Study Group. Randomized Study with the Sirolimus-Coated Bx Velocity Balloon-Expandable Stent in the Treatment of Patients with de Novo Native Coronary Artery Lesions. A randomized comparison of a sirolimus-eluting stent with a standard stent for coronary revascularization. N Engl J Med. 2002;346(23):1773-80. PubMed PMID: 12050336.
Original research

research

citations per year

$3013-273.9$

research 
Table 6 Most cited articles (Continued)

\begin{tabular}{|c|c|c|c|c|}
\hline Rank & Articles & Article type & $\begin{array}{l}\text { Total } \\
\text { citations }\end{array}$ & $\begin{array}{l}\text { Citations } \\
\text { per year }\end{array}$ \\
\hline 91. & $\begin{array}{l}\text { Furberg CD, Wright JT, Davis BR, Cutler JA, Alderman M, Black H, Cushman W, Grimm R, Haywood L, } \\
\text { Leenen F, Oparil S, Probstfield J, Whelton P, Nwachuku C, Gordon D, Proschan M, Einhorn P, et al. } \\
\text { ALLHAT Officers and Coordinators for the ALLHAT Collaborative Research Group. The Antihypertensive } \\
\text { and Lipid-Lowering Treatment to Prevent Heart Attack Trial. Major outcomes in high-risk hypertensive } \\
\text { patients randomized to angiotensin-converting enzyme inhibitor or calcium channel blocker vs diur- } \\
\text { etic: The Antihypertensive and Lipid-Lowering Treatment to Prevent Heart Attack Trial (ALLHAT). JAMA. } \\
\text { 2002;288(23):2981-97. PubMed PMID: 12479763. }\end{array}$ & $\begin{array}{l}\text { Original } \\
\text { research }\end{array}$ & 2752 & 183.5 \\
\hline 92. & $\begin{array}{l}\text { Appel LJ, Moore TJ, Obarzanek E, Vollmer WM, Svetkey LP, Sacks FM, Bray GA, Vogt TM, Cutler JA, } \\
\text { Windhauser MM, Lin PH, Karanja N. A clinical trial of the effects of dietary patterns on blood pressure. } \\
\text { DASH Collaborative Research Group. N Engl J Med. 1997;336(16):1117-24. PubMed PMID: } 9099655 .\end{array}$ & $\begin{array}{l}\text { Original } \\
\text { research }\end{array}$ & 2741 & 137.1 \\
\hline 93. & $\begin{array}{l}\text { National Lung Screening Trial Research Team, Aberle DR, Adams AM, Berg CD, Black WC, Clapp JD, } \\
\text { Fagerstrom RM, Gareen IF, Gatsonis C, Marcus PM, Sicks JD. Reduced lung-cancer mortality with low-dose } \\
\text { computed tomographic screening. N Engl J Med. } 2011 \text { Aug 4;365(5):395-409. PubMed PMID: } 21714641 .\end{array}$ & $\begin{array}{l}\text { Original } \\
\text { research }\end{array}$ & 2726 & 454.3 \\
\hline 94. & $\begin{array}{l}\text { McHutchison JG, Gordon SC, Schiff ER, Shiffman ML, Lee WM, Rustgi VK, Goodman ZD, Ling MH, Cort S, } \\
\text { Albrecht JK. Interferon alfa-2b alone or in combination with ribavirin as initial treatment for chronic hepatitis } \\
\text { C. Hepatitis Interventional Therapy Group. N Engl J Med. 1998;339(21):1485-92. PubMed PMID: } 9819446 .\end{array}$ & $\begin{array}{l}\text { Original } \\
\text { research }\end{array}$ & 2725 & 143.4 \\
\hline 95. & $\begin{array}{l}\text { Pitt B, Remme W, Zannad F, Neaton J, Martinez F, Roniker B, Bittman R, Hurley S, Kleiman J, Gatlin M; } \\
\text { Eplerenone Post-Acute Myocardial Infarction Heart Failure Efficacy and Survival Study Investigators. } \\
\text { Eplerenone, a selective aldosterone blocker, in patients with left ventricular dysfunction after myocar- } \\
\text { dial infarction. N Engl J Med. 2003;348(14):1309-21. PubMed PMID: } 12668699 \text {. }\end{array}$ & $\begin{array}{l}\text { Original } \\
\text { research }\end{array}$ & 2713 & 193.8 \\
\hline 96. & $\begin{array}{l}\text { CONSENSUS Trial Study Group. Effects of enalapril on mortality in severe congestive heart failure. } \\
\text { Results of the Cooperative North Scandinavian Enalapril Survival Study (CONSENSUS). N Engl J Med. } \\
1987 \text { Jun 4;316(23):1429-35. PubMed PMID: 2883575. }\end{array}$ & $\begin{array}{l}\text { Original } \\
\text { research }\end{array}$ & 2693 & 89.8 \\
\hline 97. & $\begin{array}{l}\text { Hébert PC, Wells G, Blajchman MA, Marshall J, Martin C, Pagliarello G, Tweeddale M, Schweitzer I, Yetisir } \\
\text { E. A multicenter, randomized, controlled clinical trial of transfusion requirements in critical care. } \\
\text { Transfusion Requirements in Critical Care Investigators. Canadian Critical Care Trials Group. N Engl J } \\
\text { Med. 1999;340(6):409-17. PubMed PMID: } 9971864 .\end{array}$ & $\begin{array}{l}\text { Original } \\
\text { research }\end{array}$ & 2687 & 149.3 \\
\hline 98. & $\begin{array}{l}\text { Cardiac Arrhythmia Suppression Trial (CAST) Investigators. Preliminary report: effect of encainide and } \\
\text { flecainide on mortality in a randomized trial of arrhythmia suppression after myocardial infarction. N } \\
\text { Engl J Med. 1989;321(6):406-12. PubMed PMID: } 2473403 \text {. }\end{array}$ & $\begin{array}{l}\text { Secondary } \\
\text { analysis }\end{array}$ & 2683 & 95.8 \\
\hline 99. & $\begin{array}{l}\text { Demetri GD, von Mehren M, Blanke CD, Van den Abbeele AD, Eisenberg B, Roberts PJ, Heinrich MC, } \\
\text { Tuveson DA, Singer S, Janicek M, Fletcher JA, Silverman SG, Silberman SL, Capdeville R, Kiese B, Peng B, } \\
\text { Dimitrijevic S, Druker BJ, Corless C, Fletcher CD, Joensuu H. Efficacy and safety of imatinib mesylate in } \\
\text { advanced gastrointestinal stromal tumors. N Engl J Med. 2002;347(7):472-80. PubMed PMID: } 12181401 .\end{array}$ & $\begin{array}{l}\text { Original } \\
\text { research }\end{array}$ & 2653 & 176.9 \\
\hline 100. & $\begin{array}{l}\text { Levey AS, Coresh J, Greene T, Stevens LA, Zhang YL, Hendriksen S, Kusek JW, Van Lente F; Chronic } \\
\text { Kidney Disease Epidemiology Collaboration. Using standardized serum creatinine values in the } \\
\text { modification of diet in renal disease study equation for estimating glomerular filtration rate. Ann Intern } \\
\text { Med. 2006;145(4):247-54. PubMed PMID: } 16908915 .\end{array}$ & Methods & 2650 & 240.9 \\
\hline
\end{tabular}

Note: Most cited (top-100) articles

research [72-75], most of these highly cited RCTs addressed interventions for burdensome conditions that are health priorities in Western countries [76, 77]. Funding of (international, collaborative) RCTs may come from varying sources including commercial and non-commercial sponsors. However, previous analyses of RCT-related articles published in high-IF journals have suggested that study sponsors may influence how RCTs are designed, conducted and reported, sometimes serving financial rather than public interests [78]. Given that research funding is often restricted, the scientific community is responsible for using the available resources most efficiently when exploring research priorities to afford knowledge users and population health needs [76, 77, 79, 80].

Our findings suggest that women are vastly underrepresented in the group of most prolific scientists publishing in high-impact medical journals. This is in direct contrast to recent studies that have identified a gender gap in research publications [81-84]. For example, a previous study [84] showed that women in first authorship positions increased from $27 \%$ in 1994 to $37 \%$ in 2014 in leading medical journals (including Annals of Internal Medicine, $J A M A$ Internal Medicine, The BMJ, JAMA, The Lancet and The New England Journal of Medicine), but progress has plateaued or declined since 2009. An urgent need exists to investigate the underlying causes of the potential gender gap to help identify publication practices and strategies to increase women's influence $[82,84]$.

Several limitations exist in our study. First, we characterised the knowledge structures generated by a large number of articles published in major medical journals that are included in the WoS database. 
Table 7 Most prolific journals and most commonly used keywords per journal

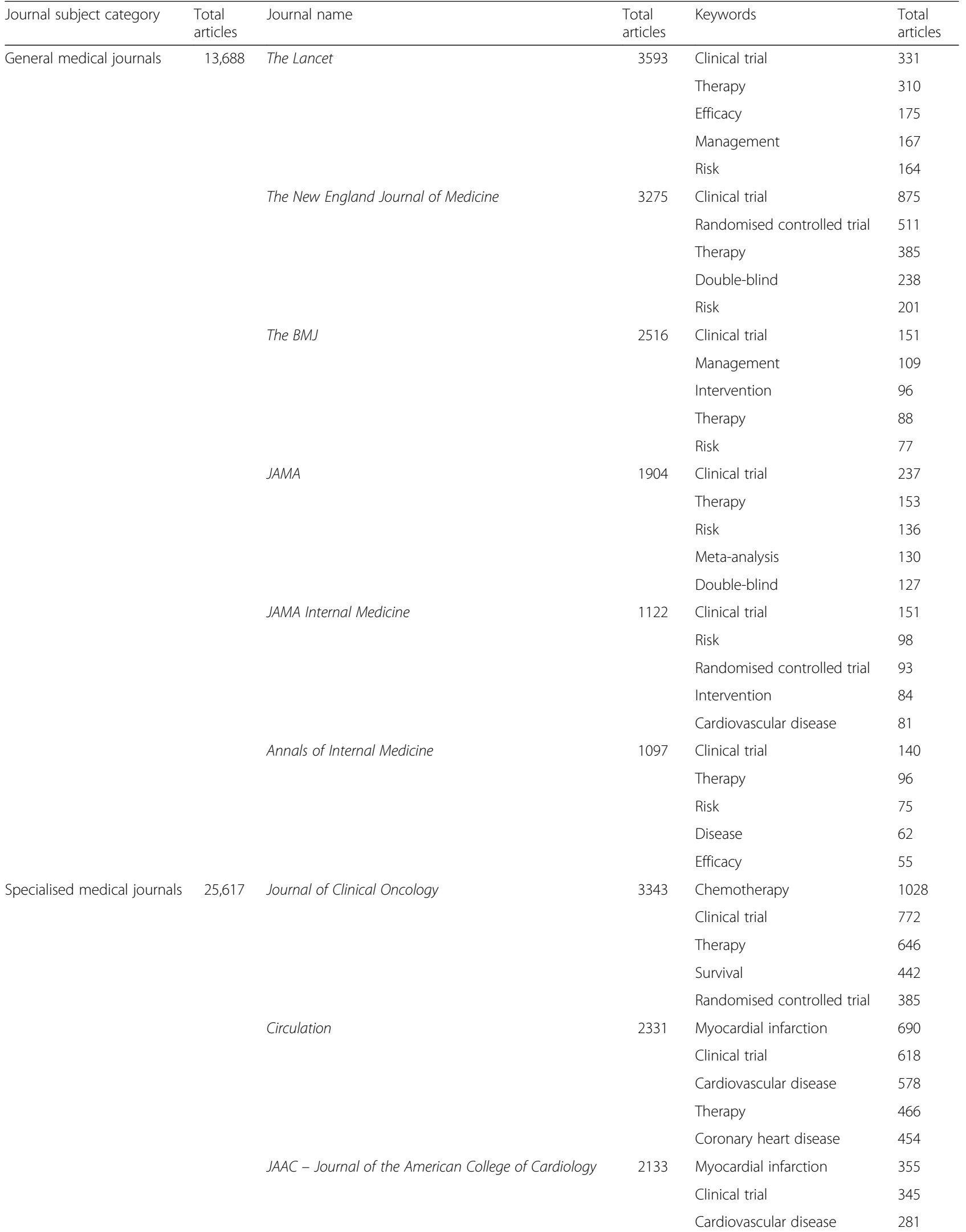


Table 7 Most prolific journals and most commonly used keywords per journal (Continued)

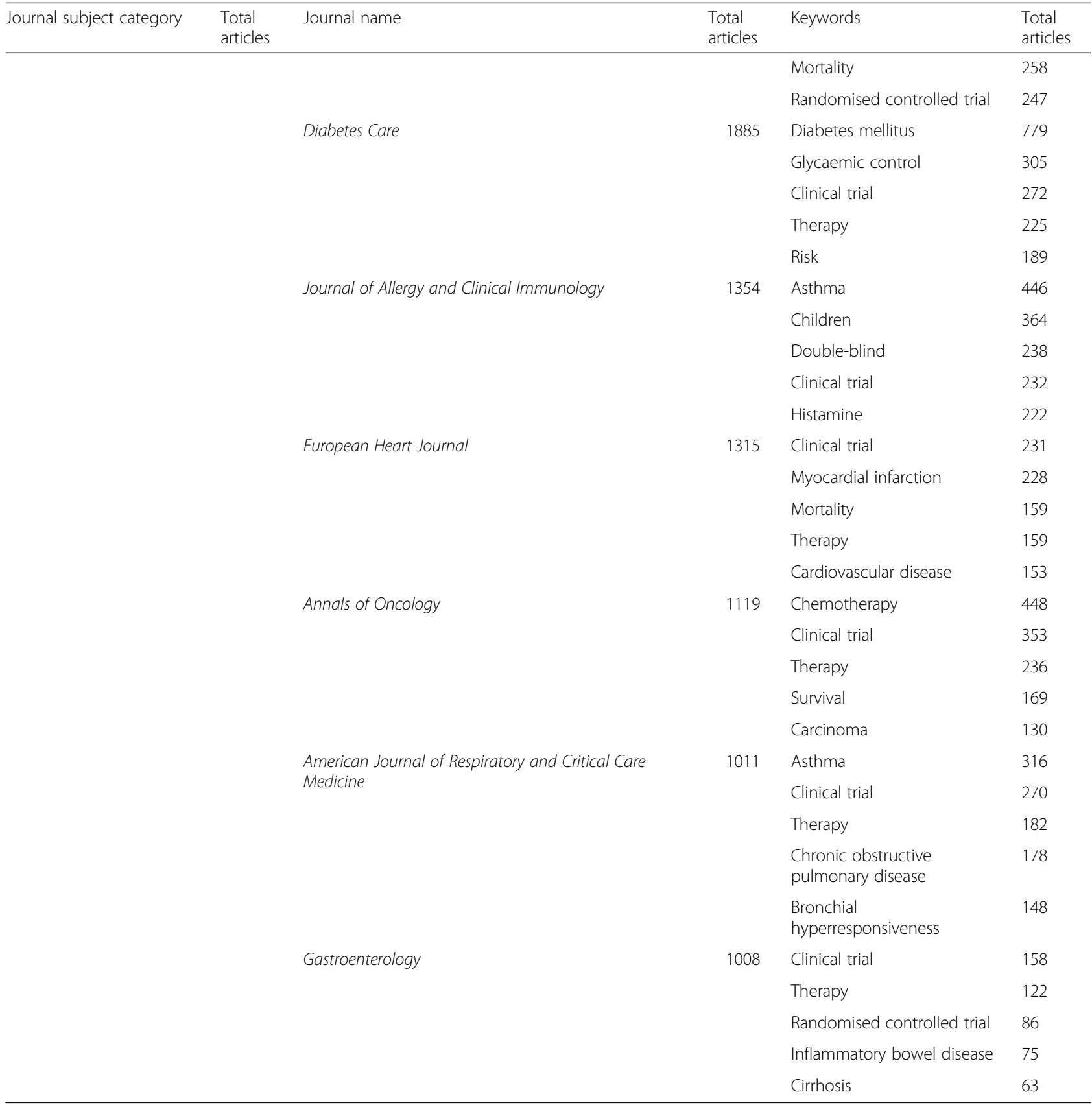

Note: Journals with at least 1000 articles. Keyword data refer to the period 1990-2017

However, our results are limited to a subset of all clinical-trial-related articles published in 40 leading medical journals. We suspect that these articles represent those that have great implications for clinical practice and that are relevant to clinical practice guidelines and healthcare regulators. Although the publication production analysed has been drawn from an exhaustive analysis of the biomedical literature, possibly, the search missed some relevant articles (and journals). Some reports may be published in journals without being indexed as RCTs, making them difficult to identify. Second, as in many bibliometric analyses, the normalisation of the different names of an author, country and funding sources is fundamentally important to avoiding potential errors. We conducted a careful manual validation of the references and textual data to avoid typographical, transcription and/or indexing errors. However, we recognize this procedure does not assure complete certainty. Third, the affiliation addresses of authors do not necessarily 
reflect the country where the research was conducted or the research funding source. Fourth, topical analysis that extracts a set of unique keywords, word profiles and co-words may indicate intellectual organization in publication production, albeit with inherent limitations $[85,86]$. Fifth, the use of citation analysis carries some problems [87-91]. A potential length time-effect bias exists, which puts the more recent articles at a disadvantage. In addition, the biomedical literature is rich in barriers and motivations for publication and citation preferences [87], including self-citation (bias towards one's own work) [88], language bias (bias towards publishing and citing English articles), omission bias (bias whereby competitors are purposely not cited), and selective reporting and publication bias (bias in which "negative" results are withheld from publication and citation) [89-92]. In addition, citations are also treated as equal regardless of whether research is being cited for its positive contribution to the field or because it is being criticized. Finally, our methods represent only a mapping approach, which could be complemented further by more detailed analyses such as by examining the content (e.g. differences in journal or author characteristics between publicly funded and industry-funded studies, designs/methodology, etc.), the reporting and the reproducible research practices through research of research ("meta-research") studies [92-98].

\section{Conclusion}

The global analysis presented in this study provides evidence of the scientific growth of RCT- related articles published in high-IF medical journals. Over the last 50 years, publication activity in leading medical journals has increased, with Western countries (most notably, the United States) leading but with low- and middle-income countries showing very limited representation. Our analysis contributes to a better conceptualization and understanding of RCT articles and identified the main areas of research, the most influential publication sources chosen for their scientific dissemination and the major scientific leaders. Given the dynamic nature of the field, whether the growth trend remains the same in the coming years and how the characteristics of the field change over time will be interesting to see.

\section{Supplementary information}

Supplementary information accompanies this paper at https://doi.org/10. 1186/s13063-019-3944-9.

Additional file 1. Full strategy in PubMed/MEDLINE.

Additional file 2. Data extraction and normalisation processes.

Additional file 3. Reporting checklist.

Additional file 4. List of PMID for included articles.
Additional file 5. List of excluded articles.

Additional file 6. Exploratory analysis of topical data.

Declaration of transparency

FC- $L$ affirms that this manuscript is an honest, accurate and transparent account of the study being reported, that no important aspects of the study have been omitted, and that any discrepancies from the study as planned (and, if relevant, registered) have been explained.

\section{Authors' contributions}

FC-L, RA-B, RT-S and AA-A contributed to conceptualizing and designing the study. FC-L and AA-A supervised the study. AA-A curated the data. AA-A and FC-L performed data analysis and visualizations. FC-L, RA-B, LC, BH, RT-S, DM and $A A-A$ interpreted the study findings. FC-L drafted the first version of the manuscript. RA-B, LC, BH, RT-S, DM and AA-A commented for important intellectual content and made major revisions. All authors read and approved the final version of the manuscript. All authors meet the ICMJE criteria for authorship. FC-L and AA-A accept full responsibility for the finished manuscript and controlled the decision to publish.

\section{Funding}

FC-L and RT-S are supported by the Institute of Health Carlos III/CIBERSAM. $\mathrm{BH}$ is supported by a New Investigator Award from the Canadian Institutes of Health Research and the Drug Safety and Effectiveness Network. DM is supported by a University Research Chair, University of Ottawa. The funders were not involved in the design of the study or the decision to submit the manuscript for publication nor were they involved in aspects of the study conduct. The views expressed in this manuscript are those of the authors and may not be understood or quoted as being made on behalf of, or as reflecting the position of, the funder(s) or any institution.

\section{Availability of data and materials}

With the publication of this manuscript, the full dataset will be freely available online in the Open Science Framework (https://osf.io/r2vw5/), a secure online repository for research data.

Ethics approval and consent to participate

This study outlines a cross-sectional analysis of secondary data and, hence, does not require ethical approval or consent to participate.

Consent for publication

Not applicable.

Competing interests

The authors declare that they have no competing interests.

\section{Author details}

1 Department of Health Planning and Economics, National School of Public Health, Institute of Health Carlos III, Madrid, Spain. ²Department of Medicine, University of Valencia/INCLIVA Health Research Institute and CIBERSAM, Valencia, Spain. ${ }^{3}$ Clinical Epidemiology Program, Ottawa Hospital Research Institute (OHRI), Ottawa, Ontario, Canada. ${ }^{4}$ Ingenio-Spanish National Research Council (CSIC) and Universitat Politècnica de Valencia (UPV), Valencia, Spain. ${ }^{5}$ Information and Social and Health Research Unit (UISYS), University of Valencia and Spanish National Research Council (CSIC), Valencia, Spain. ${ }^{6}$ Ear, Nose and Throat Department, Guy's Hospital, London, UK. 'Department of Clinical Epidemiology, Erasmus University Medical Centre, Rotterdam, The Netherlands. ${ }^{8}$ School of Epidemiology and Public Health, University of Ottawa, Ottawa, Ontario, Canada. ${ }^{9}$ Department of History of Science and Documentation, University of Valencia, Valencia, Spain.

Received: 23 July 2019 Accepted: 29 November 2019 Published online: 07 January 2020

\section{References}

1. Schulz KF, Grimes DA. The Lancet Handbook of essential concepts in clinical research. London: Elsevier Ltd.; 2006.

2. Gabriel SE, Normand SL. Getting the methods right--the foundation of patient-centered outcomes research. N Engl J Med. 2012;367(9):787-90. 
3. Jadad AR. Randomised controlled trials: a user's guide. London: BMJ Books; 1998.

4. Begg C, Cho M, Eastwood S, Horton R, Moher D, Olkin I, et al. Improving the quality of reporting of randomized controlled trials. The CONSORT statement. JAMA. 1996;276(8):637-9.

5. Tsay MY, Yang YH. Bibliometric analysis of the literature of randomized controlled trials. J Med Libr Assoc. 2005;93(4):450-8.

6. Yusuf $S$, Collins R, Peto R. Why do we need some large, simple randomized trials? Stat Med. 1984;3(4):409-22.

7. Roundtable on Value and Science-Driven Health Care, Forum on Drug Discovery, Development, and Translation, Board on Health Sciences Policy, Institute of Medicine. Large simple trials and knowledge generation in a learning health system: workshop summary. Washington (DC): National Academies Press; 2013

8. Sackett DL, Rosenberg WM, Gray JA, Haynes RB, Richardson WS. Evidence based medicine: what it is and what it isn't. BMJ. 1996;312(7023):71-2.

9. Zarin DA, Tse T, Williams RJ, Carr S. Trial reporting in ClinicalTrials.gov - the final rule. N Engl J Med. 2016;375(20):1998-2004.

10. Zarin DA, Tse T, Ide NC. Trial registration at ClinicalTrials.gov between May and October 2005. N Engl J Med. 2005;353(26):2779-87.

11. Taichman DB, Backus J, Baethge C, Bauchner H, de Leeuw PW, Drazen JM, et al. Sharing clinical trial data: a proposal from the International Committee of Medical Journal Editors. PLoS Med. 2016;13(1):e1001950.

12. Naudet F, Sakarovitch C, Janiaud P, Cristea I, Fanelli D, Moher D, et al. Data sharing and reanalysis of randomized controlled trials in leading biomedical journals with a full data sharing policy: survey of studies published in The BMJ and PLOS Medicine. BMJ. 2018:360:k400.

13. Moher D, Schulz KF, Altman D. CONSORT Group (Consolidated Standards of Reporting Trials). The CONSORT statement: revised recommendations for improving the quality of reports of parallel-group randomized trials. JAMA. 2001;285(15):1987-91.

14. Schulz KF, Altman DG, Moher D, CONSORT Group. CONSORT 2010 Statement: updated guidelines for reporting parallel group randomised trials. Trials. 2010;11:32.

15. Chan AW, Tetzlaff JM, Altman DG, Laupacis A, Gøtzsche PC, Krleža-Jerić K, et al. SPIRIT 2013 statement: defining standard protocol items for clinical trials. Ann Intern Med. 2013;158(3):200-7.

16. Thelwall M, Kousha K. Are citations from clinical trials evidence of higher impact research? An analysis of ClinicalTrials.gov. Scientometrics. 2016; 109(2):1341-51.

17. Brueton VC, Vale CL, Choodari-Oskooei B, Jinks R, Tierney JF. Measuring the impact of methodological research: a framework and methods to identify evidence of impact. Trials. 2014;15:464.

18. Hays M, Andrews M, Wilson R, Callender D, O'Malley PG, Douglas K. Reporting quality of randomised controlled trial abstracts among highimpact general medical journals: a review and analysis. BMJ Open. 2016;6(7):e011082.

19. Ghimire S, Kyung E, Kang W, Kim E. Assessment of adherence to the CONSORT statement for quality of reports on randomized controlled trial abstracts from four high-impact general medical journals. Trials. 2012;13:77.

20. Charles P, Giraudeau B, Dechartres A, Baron G, Ravaud P. Reporting of sample size calculation in randomised controlled trials: review. BMJ. 2009;338:b1732.

21. Contopoulos-loannidis DG, Karvouni A, Kouri I, loannidis JP. Reporting and interpretation of SF-36 outcomes in randomised trials: systematic review. BMJ. 2009;338:a3006.

22. Pitrou I, Boutron I, Ahmad N, Ravaud P. Reporting of safety results in published reports of randomized controlled trials. Arch Intern Med. 2009; 169(19):1756-61

23. Ebrahim S, Montoya L, Kamal El Din M, Sohani ZN, Agarwal A, Bance S, et al, Randomized trials are frequently fragmented in multiple secondary publications. J Clin Epidemiol. 2016;79:130-9.

24. Alsheikh-Ali AA, Qureshi W, Al-Mallah MH, loannidis JP. Public availability of published research data in high-impact journals. PLoS One. 2011;6(9):e24357.

25. Mathieu S, Boutron I, Moher D, Altman DG, Ravaud P. Comparison of registered and published primary outcomes in randomized controlled trials. JAMA. 2009;302(9):977-84.

26. Trikalinos NA, Evangelou E, loannidis JP. Falsified papers in high-impact journals were slow to retract and indistinguishable from nonfraudulent papers. J Clin Epidemiol. 2008;61(5):464-70.
27. Siontis KC, Evangelou E, loannidis JP. Magnitude of effects in clinical trials published in high-impact general medical journals. Int J Epidemiol. 2011; 40(5):1280-91.

28. Ioannidis JP. Contradicted and initially stronger effects in highly cited clinical research. JAMA. 2005;294(2):218-28.

29. Haynes RB, McKibbon KA, Wilczynski NL, Walter SD, Werre SR, Hedges Team. Optimal search strategies for retrieving scientifically strong studies of treatment from Medline: analytical survey. BMJ. 2005;330(7501):1179.

30. Sugimoto $C R$, Larivière $V$. Measuring research: what everyone needs to know ${ }^{\oplus}$. Oxford: Oxford University Press; 2018.

31. Catalá-López F, Alonso-Arroyo A, Hutton B, Aleixandre-Benavent R, Moher D. Global collaborative networks on meta-analyses of randomized trials published in high impact factor medical journals: a social network analysis. BMC Med. 2014;12:15.

32. Börner K, Polley DE. Visual insights: a practical guide to making sense of data. Cambridge, Massachusetts: MIT Press; 2014.

33. Batagelj V, Mrvar A. Pajek 1.28. Program for large network analysis. Ljubljana: University of Ljubljana; 2010.

34. Moher D, Liberati A, Tetzlaff J, Altman DG, PRISMA Group. Preferred reporting items for systematic reviews and meta-analyses: the PRISMA statement. PLoS Med. 2009;6(7):e1000097.

35. Bland JM, Altman DG. Statistical methods for assessing agreement between two methods of clinical measurement. Lancet. 1986;1(8476):307-10.

36. Diabetes Control and Complications Trial Research Group, Nathan DM, Genuth S, Lachin J, Cleary P, Crofford O, et al. The effect of intensive treatment of diabetes on the development and progression of long-term complications in insulin-dependent diabetes mellitus. N Engl J Med. 1993:329(14):977-86.

37. UK Prospective Diabetes Study (UKPDS) Group. Intensive blood-glucose control with sulphonylureas or insulin compared with conventional treatment and risk of complications in patients with type 2 diabetes (UKPDS 33). Lancet. 1998;352(9131):837-53.

38. Knowler WC, Barrett-Connor E, Fowler SE, Hamman RF, Lachin JM, Walker EA, Nathan DM, Diabetes Prevention Program Research Group. Reduction in the incidence of type 2 diabetes with lifestyle intervention or metformin. $N$ Engl J Med. 2002;346(6):393-403.

39. Tuomilehto J, Lindström J, Eriksson JG, Valle TT, Hämäläinen H, llanneParikka P, et al. Prevention of type 2 diabetes mellitus by changes in lifestyle among subjects with impaired glucose tolerance. N Engl J Med. 2001;344(18):1343-50.

40. UK Prospective Diabetes Study (UKPDS) Group. Effect of intensive blood-glucose control with metformin on complications in overweight patients with type 2 diabetes (UKPDS 34). Lancet. 1998;352(9131):854-65 PubMed PMID: 9742977.

41. Action to Control Cardiovascular Risk in Diabetes Study Group. Effects of intensive glucose lowering in type 2 diabetes. N Engl J Med. 2008;358(24):2545-59.

42. Rossouw JE, Anderson GL, Prentice RL, LaCroix AZ, Kooperberg C, Stefanick $M L$, et al. Risks and benefits of estrogen plus progestin in healthy postmenopausal women: principal results From the Women's Health Initiative randomized controlled trial. JAMA. 2002;288(3):321-33.

43. Hulley S, Grady D, Bush T, Furberg C, Herrington D, Riggs B, et al. Randomized trial of estrogen plus progestin for secondary prevention of coronary heart disease in postmenopausal women. Heart and Estrogen/ progestin Replacement Study (HERS) Research Group. JAMA. 1998:280(7):605-13.

44. Stupp R, Mason WP, van den Bent MJ, Weller M, Fisher B, Taphoorn MJ, et al. Radiotherapy plus concomitant and adjuvant temozolomide for glioblastoma. N Engl J Med. 2005;352(10):987-96.

45. Hurwitz H, Fehrenbacher L, Novotny W, Cartwright T, Hainsworth J, Heim W, et al. Bevacizumab plus irinotecan, fluorouracil, and leucovorin for metastatic colorectal cancer. N Engl J Med. 2004;350(23):2335-42.

46. Slamon DJ, Leyland-Jones B, Shak S, Fuchs H, Paton V, Bajamonde A, et al. Use of chemotherapy plus a monoclonal antibody against HER2 for metastatic breast cancer that overexpresses HER2. N Engl J Med. 2001;344(11):783-92.

47. Fisher B, Costantino JP, Wickerham DL, Redmond CK, Kavanah M, Cronin WM, et al. Tamoxifen for prevention of breast cancer: report of the National Surgical Adjuvant Breast and Bowel Project P-1 Study. J Natl Cancer Inst. 1998:90(18):1371-88.

48. Hodi FS, O'Day SJ, McDermott DF, Weber RW, Sosman JA, Haanen JB, et al. Improved survival with ipilimumab in patients with metastatic melanoma. N Engl J Med. 2010;363(8):711-23. 
49. Chapman PB, Hauschild A, Robert C, Haanen JB, Ascierto P, Larkin J, et al. Improved survival with vemurafenib in melanoma with BRAF V600E mutation. N Engl J Med. 2011;364(26):2507-16.

50. Llovet JM, Ricci S, Mazzaferro V, Hilgard P, Gane E, Blanc JF, et al. Sorafenib in advanced hepatocellular carcinoma. N Engl J Med. 2008;359(4):378-90. https://doi.org/10.1056/NEJMoa0708857.

51. Pedersen TR, Kjekshus J, Berg K, Haghfelt T, Faergeman O, Thorgeirsson G, et al. Randomised trial of cholesterol lowering in 4444 patients with coronary heart disease: the Scandinavian Simvastatin Survival Study (4S). Lancet. 1994;344(8934):1383-9.

52. Shepherd J, Cobbe SM, Ford I, Isles CG, Lorimer AR, MacFarlane PW, et al. Prevention of coronary heart disease with pravastatin in men with hypercholesterolemia. N Engl J Med. 1995;333(20):1301-7.

53. Sacks FM, Pfeffer MA, Moye LA, Rouleau JL, Rutherford JD, Cole TG, et al. The effect of pravastatin on coronary events after myocardial infarction in patients with average cholesterol levels. Cholesterol and Recurrent Events Trial investigators. N Engl J Med. 1996;335(14):1001-9.

54. Collins R, Armitage J, Parish S, Sleight P, Peto R. Heart Protection Study Collaborative Group. MRC/BHF Heart Protection Study of cholesterol lowering with simvastatin in 20.536 high-risk individuals: a randomised placebo-controlled trial. Lancet. 2002;360(9326):7-22.

55. Heart Outcomes Prevention Evaluation Study Investigators, Yusuf S, Sleight P, Pogue J, Bosch J, Davies R, Dagenais G. Effects of an angiotensinconverting-enzyme inhibitor, ramipril, on cardiovascular events in high-risk patients. N Engl J Med. 2000;342(3):145-53.

56. Pitt B, Zannad F, Remme WJ, Cody R, Castaigne A, Perez A, et al. The effect of spironolactone on morbidity and mortality in patients with severe heart failure. Randomized Aldactone Evaluation Study Investigators. N Engl J Med. 1999;341(10):709-17

57. Pfeffer MA, Braunwald E, Moyé LA, Basta L, Brown EJ Jr, Cuddy TE, et al. Effect of captopril on mortality and morbidity in patients with left ventricular dysfunction after myocardial infarction. Results of the survival and ventricular enlargement trial. N Engl J Med. 1992;327(10):669-77.

58. Brenner BM, Cooper ME, de Zeeuw D, Keane WF, Mitch WE, Parving HH, et al. Effects of losartan on renal and cardiovascular outcomes in patients with type 2 diabetes and nephropathy. N Engl J Med. 2001;345(12):861-9.

59. Lewis EJ, Hunsicker LG, Bain RP, Rohde RD. The effect of angiotensinconverting-enzyme inhibition on diabetic nephropathy. The Collaborative Study Group. N Engl J Med. 1993;329(20):1456-62.

60. National Institute of Neurological Disorders and Stroke rt-PA Stroke Study Group. Tissue plasminogen activator for acute ischemic stroke. N Engl J Med. 1995;333(24):1581-7.

61. Connolly SJ, Ezekowitz MD, Yusuf S, Eikelboom J, Oldgren J, Parekh A, et al. Dabigatran versus warfarin in patients with atrial fibrillation. N Engl J Med. 2009;361(12):1139-51.

62. Yusuf S, Zhao F, Mehta SR, Chrolavicius S, Tognoni G, Fox KK. Clopidogrel in Unstable Angina to Prevent Recurrent Events Trial Investigators. Effects of clopidogrel in addition to aspirin in patients with acute coronary syndromes without ST-segment elevation. N Engl J Med. 2001;345(7):494-502.

63. CAPRIE Steering Committee, Gent M, Beaumont D, Blanchard J, Bousser MG, Coffman J, Easton JD, et al. A randomised. blinded. trial of clopidogrel versus aspirin in patients at risk of ischaemic events (CAPRIE). Lancet. 1996;348(9038):1329-39.

64. Røttingen JA, Regmi S, Eide M, Young AJ, Viergever RF, Ardal C, et al. Mapping of available health research and development data: what's there, what's missing, and what role is there for a global observatory? Lancet. 2013;382(9900):1286-307.

65. Moses H 3rd, Matheson DH, Cairns-Smith S, George BP, Palisch C, Dorsey ER. The anatomy of medical research: US and international comparisons. JAMA. 2015;313(2):174-89.

66. Sussex J, Feng $Y$, Mestre-Ferrandiz J, Pistollato M, Hafner M, Burridge $P$, et al Quantifying the economic impact of government and charity funding of medical research on private research and development funding in the United Kingdom. BMC Med. 2016;14:32.

67. Shapiro HT, Meslin EM. Ethical issues in the design and conduct of clinical trials in developing countries. N Engl J Med. 2001;345(2):139-42.

68. Berkley JA. Randomised trials in developing countries. Arch Dis Child. 2014;99(7):607-8.

69. Knepper TC, McLeod HL. When will clinical trials finally reflect diversity? Nature. 2018;557(7704):157-9.
70. Sumathipala A, Siribaddana S, Patel V. Under-representation of developing countries in the research literature: ethical issues arising from a survey of five leading medical journals. BMC Med Ethics. 2004;5:E5.

71. Uthman OA, Okwundu Cl, Wiysonge CS, Young T, Clarke A. Citation classics in systematic reviews and meta-analyses: who wrote the top 100 most cited articles? PLoS One. 2013;8(10):e78517.

72. Atal I, Trinquart L, Ravaud P, Porcher R. A mapping of 115,000 randomized trials revealed a mismatch between research effort and health needs in non-high-income regions. J Clin Epidemiol. 2018;98:123-32.

73. Emdin CA, Odutayo A, Hsiao AJ, Shakir M, Hopewell S, Rahimi K, Altman DG. Association between randomised trial evidence and global burden of disease: cross sectional study (Epidemiological Study of Randomized Trials-ESORT). BMJ. 2015:350:h117.

74. Catalá-López F, García-Altés A, Alvarez-Martín E, Gènova-Maleras R, MorantGinestar $C$. Does the development of new medicinal products in the European Union address global and regional health concerns? Popul Health Metr. 2010;8:34.

75. Isaakidis P, Swingler GH, Pienaar E, Volmink J, loannidis JP. Relation between burden of disease and randomised evidence in sub-Saharan Africa: survey ofresearch. BMJ. 2002;324(7339):702.

76. GBD 2017 Disease and Injury Incidence and Prevalence Collaborators. Global, regional, and national incidence, prevalence, and years lived with disability for 354 diseases and injuries for 195 countries and territories, 1990-2017: a systematic analysis for the Global Burden of Disease Study 2017. Lancet. 2018;392(10159):1789-858.

77. GBD 2017 DALYs and HALE Collaborators. Global, regional, and national disability-adjusted life-years (DALYS) for 359 diseases and injuries and healthy life expectancy (HALE) for 195 countries and territories, 1990-2017: a systematic analysis for the Global Burden of Disease Study 2017. Lancet. 2018; 392(10159):1859-922

78. Rasmussen K, Bero L, Redberg R, Gøtzsche PC, Lundh A. Collaboration between academics and industry in clinical trials: cross sectional study of publications and survey of lead academic authors. BMJ. 2018;363: k3654.

79. Chalmers I, Bracken MB, Djulbegovic B, Garattini S, Grant J, Gülmezoglu AM, et al. How to increase value and reduce waste when research priorities are set. Lancet. 2014;383(9912):156-65.

80. Moher D, Glasziou P, Chalmers I, Nasser M, Bossuyt PM, Korevaar DA, et al. Increasing value and reducing waste in biomedical research: who's listening? Lancet. 2016;387(10027):1573-86.

81. van den Besselaar P, Sandström U. Vicious circles of gender bias, lower positions, and lower performance: gender differences in scholarly productivity and impact. PLoS One. 2017;12(8):e0183301.

82. Lundine J, Bourgeault IL, Clark J, Heidari S, Balabanova D. The gendered system of academic publishing. Lancet. 2018;391(10132):1754-6.

83. Lundine J, Bourgeault IL, Clark J, Heidari S, Balabanova D. Gender bias in academia. Lancet. 2019;393(10173):741-3.

84. Filardo G, da Graca B, Sass DM, Pollock BD, Smith EB, Martinez MA. Trends and comparison of female first authorship in high impact medical journals: observational study (1994-2014). BMJ. 2016;352:i847.

85. Leydesdorff L. Words and co-words as indicators of intellectual organization. Research Policy. 1989;18(4):209-23.

86. Leydesdorff L. Why words and co-words cannot map the development of the sciences. J Am Soc Inf Sci. 1997;48(5):418-27.

87. Greenberg SA. How citation distortions create unfounded authority: analysis of a citation network. BMJ. 2009;339:b2680.

88. Mishra S, Fegley BD, Diesner J, Torvik VI. Self-citation is the hallmark of productive authors, of any gender. PLoS One. 2018;13(9):e0195773.

89. Dwan K, Gamble C, Williamson PR, Kirkham JJ, Reporting Bias Group. Systematic review of the empirical evidence of study publication bias and outcome reporting bias - an updated review. PLoS One. 2013;8(7):e66844

90. Phillips AT, Desai NR, Krumholz HM, Zou CX, Miller JE, Ross JS. Association of the FDA Amendment Act with trial registration, publication, and outcome reporting. Trials. 2017;18(1):333

91. Goldacre B, Drysdale H, Dale A, Milosevic I, Slade E, Hartley P, et al. COMPare: a prospective cohort study correcting and monitoring 58 misreported trials in real time. Trials. 2019;20(1):118.

92. Goldacre B, Drysdale H, Marston C, Mahtani KR, Dale A, Milosevic I, et al. COMPare: Qualitative analysis of researchers' responses to critical correspondence on a cohort of 58 misreported trials. Trials. 2019;20(1):124. 
93. Dechartres A, Bond EG, Scheer J, Riveros C, Atal I, Ravaud P. Reporting of statistically significant results at ClinicalTrials.gov for completed superiority randomized controlled trials. BMC Med. 2016;14(1):192.

94. Dechartres A, Trinquart L, Atal I, Moher D, Dickersin K, Boutron I, et al. Evolution of poor reporting and inadequate methods over time in 20920 randomised controlled trials included in Cochrane reviews: research on research study. BMJ. 2017;357:j2490.

95. Becker JE, Krumholz HM, Ben-Josef G, Ross JS. Reporting of results in ClinicalTrials.gov and high-impact journals. JAMA. 2014;311(10):1063-5.

96. Bartlett VL, Dhruva SS, Shah ND, Ryan P, Ross JS. feasibility of using realworld data to replicate clinical trial evidence. JAMA Netw Open. 2019;2(10):e1912869

97. Wallach JD, Boyack KW, loannidis JPA. Reproducible research practices, transparency, and open access data in the biomedical literature, 2015-2017. PLoS Biol. 2018;16(11):e2006930.

98. Ioannidis JP, Fanelli D, Dunne DD, Goodman SN. meta-research: evaluation and improvement of research methods and practices. PLoS Biol. 2015; 13(10):e1002264

\section{Publisher's Note}

Springer Nature remains neutral with regard to jurisdictional claims in published maps and institutional affiliations.

- fast, convenient online submission

- thorough peer review by experienced researchers in your field

- rapid publication on acceptance

- support for research data, including large and complex data types

- gold Open Access which fosters wider collaboration and increased citations

- maximum visibility for your research: over $100 \mathrm{M}$ website views per year

At $\mathrm{BMC}$, research is always in progress. 